\title{
Composition and spatiotemporal distribution of ichthyoplankton on the continental shelf of the southern East China Sea
}

\author{
Yi-Chen Wang ${ }^{1}$ and Ming-An Lee ${ }^{1,2, *}$ \\ ${ }^{1}$ Department of Environmental Biology and Fisheries Science, National Taiwan Ocean University, Keelung City, Taiwan \\ ${ }^{2}$ Center of excellence for oceans, National Taiwan Ocean University, Keelung City, Taiwan
}

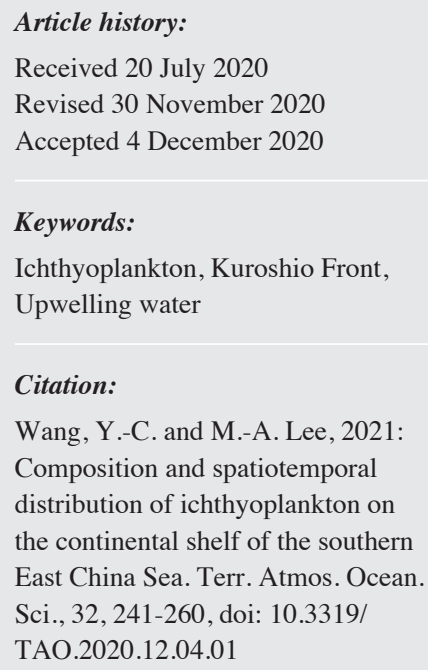

\section{Citation:}

Wang, Y.-C. and M.-A. Lee, 2021: Composition and spatiotemporal distribution of ichthyoplankton on the continental shelf of the southern East China Sea. Terr. Atmos. Ocean. Sci., 32, 241-260, doi: 10.3319/ TAO.2020.12.04.01

\begin{abstract}
This study investigated the effects of the Kuroshio Front (KF) on the continental shelf of the southern East China Sea on ichthyoplankton communities during the northeast monsoon period. According to field observations and satellite images of sea surface temperature, we documented that the KF occurred and moved nearshore between December and January before shifting seaward in March. In total, 156 species were identified among the 9896 individual larval fish collected. Multivariate analysis revealed significant differences in fish abundance and composition over time. The abundance of oceanic species increased by approximately $10 \%$ from December to January and then decreased by approximately $50 \%$ in March. Oceanic species, such as myctophid and gonostomatid fish, were dominant (37.4-86.5\%) in the oceanic waters on the offshore side of the KF. Some coastal and commercial species, such as anchovies, were dominant $(26.9-99.1 \%)$ in the neritic waters on the nearshore side of the KF from December to March. These results may have been influenced by spawning seasons and adult habitats. The strong front influenced the distribution of larval fish more than the weaker upwelling during winter did. Specifically, oceanic fish were brought into nearshore waters by Kuroshio water intrusion in winter. Most larvae were still restricted to the nearshore and offshore side by the KF, meaning that the strong KF was still a barrier separating most fish larvae assemblages, especially for those of the neritic species. The mechanism underlying the cross-frontal transport of fish larvae is more likely to occur in oceanic species, because it may be related to diel vertical migration behavior.
\end{abstract}

\section{INTRODUCTION}

Among continental margin waters, the East China Sea (ECS), which has high primary productivity due to a rich supply of nutrients from terrestrial and marine sources, is one of the world's most influential large marine ecosystems (Walsh 1991; Wollast 1993; Belkin 2009). The continental shelf of the southern ECS, a highly dynamic oceanic region, serves as a transitional area between the coastal waters of mainland China and the open waters of the western North Pacific. Several water masses - including the China Coastal Current (CCC), the Kuroshio Current (KC), the Kuroshio Branch Current (KBC), and the Taiwan Strait Warm Water (TSWW) - meet in this region during certain seasons (Jan et al. 2002, 2006; Gong et al. 2003). In general, because the

\footnotetext{
* Corresponding author

E-mail:malee@mail.ntou.edu.tw
}

northward intrusion of the $\mathrm{KBC}$ is blocked by the northeast monsoon, the $\mathrm{CCC}$ and $\mathrm{KC}$ may determine the hydrographic structure of the southern ECS at the continental break of the southern ECS in winter (Jan et al. 2002; Lie and Cho 2002; Jan and Chao 2003; Chang et al. 2008). During the weak northeast monsoon in autumn and spring, this structure is regulated by the northward intrusion of the $\mathrm{KBC}$, northward retreat of the CCC, and year-round northward flow of the KC (Jan et al. 2002, 2006; Jan and Chao 2003). However, monsoon wind-change effects on current patterns vary by year. In addition, a cold eddy caused by the upwelling of the Kuroshio subsurface water persists throughout the year (Liu et al. 1992; Wu et al. 2008), and the upwelling retains a constant supply of nutrients with high primary productivity, which supports the proliferation of marine life and various types of fisheries (Chen and Chiu 1992; Hsu et al. 2000; 
Liao et al. 2006). Furthermore, the semicircular Kuroshio Front (KF) between the shelf region and the eastern open ocean appears in wintertime; its systematic appearance is attributed to a sea surface temperature (SST) pattern similar to that of the frontal eddies at the northern KF (Chang et al. 2008). Higher concentrations of chlorophyll a are also found in the area of the SST front (Chang et al. 2008).

Ichthyoplankton are macroplankton that are planktonic for a part of their life cycle and highly sensitive to variations in the environment. The determination of ichthyoplankton populations is the most critical step in the establishment of annual fish recruitment, which is in turn essential to the operation of major commercial fisheries (Zhang and Lee 2001; Takahashi and Watanabe 2004). Data on the biodiversity and abundance of ichthyoplankton can also provide valuable information on the fish populations. Numerous studies have focused on the ecological aspects of the larval stage of fish, includings as growth (Engström-Öst and Mattila 2008), distribution (Chen et al. 2014), feeding (Carassou and Ponton 2009), community structure (Lee et al. 2013; Wang et al. 2013), and survival (Fiksen et al. 2002). Data on the composition and spatiotemporal distribution of ichthyoplankton associated with the ocean environment serve as useful references for biological and fishery studies. Biological-physical linkages are frequently observed in marine ecosystems such as estuaries (Queiroga et al. 1997; DiBacco et al. 2001), shelf-break fronts (Hsieh et al. 2007; Wang et al. 2013), and upwelling areas (Vargas and Castro 2001; Yannicelli et al. 2006).

Changes in larval fish assemblages structures in relation to hydrographic conditions such as current transportation (Sassa et al. 2006; Chen et al. 2014), seasonal changes (Hsieh et al. 2011), food availability (Chen et al. 2014), and competition (Sassa et al. 2008a) have also been extensively explored. Studies on the southern ECS have focused on the relationship between ichthyoplankton communities and environmental factors (e.g., currents, temperature, salinity, chlorophyll a level, wind field, food resources, and nutrients) subject to seasonal change. Hsieh et al. (2010) found that the summer distribution of larvae was closely linked to food sources in Taiwan waters during the southwest monsoon. Chen et al. (2016) determined that temperature is considered a critical factor affecting larval fish abundance and distribution during the northeast monsoon in the southern ECS. According to Sassa and Konishi (2015), the combination of SST and chlorophyll a concentration best explains larval fish distribution and assemblages in the southern ECS during late winter. Su et al. (2011) found that the dynamic front between the ECS shelf waters and the Kuroshio waters - driven by northeasterly or southwesterly monsoons - changed and affected the transport of fish larvae. Lo et al. (2010) contended that food availability and monsoon-induced change in current may be another critical factor affecting the distribution of larval fish assemblages during and after the northeast monsoon in the waters around Taiwan. Hsieh et al. (2007) observed that the larger bias and grading of temperature and salinity were found between two water masses of the $\mathrm{CCC}$ and $\mathrm{KC}$ on the continental shelf of the southern ECS in late-winter and that they influence the spatial distribution of nearshore and offshore fish larvae.

However, the Mainland China Coastal Front and KF have also been identified in this area in early winter (Chang et al. 2008; Wang et al. 2018). A review of studies that have assessed the relationship between the thermal front and fish larvae, such as Wang et al. (2013), revealed that the thermal front was likely to be the boundary separating various fish larvae assemblages on the continental shelf of the southern ECS over four winters. By using satellite SST images captured between December to March, Wang et al. (2018) determined that the KF shifted seaward and shoreward with the recession and intrusion of the $\mathrm{CCC}$ and $\mathrm{KC}$ in winter, respectively; similarly, the $\mathrm{KF}$, which is generated in winter, may act as a biological barrier to larval fish in the continental shelf waters of the southern ECS. According to Chen et al. (2016), the frontal area constitutes the boundary that limits the ability of mesopelagic fish of the $\mathrm{KC}$ to intrude into the waters of northern Taiwan. Sassa et al. (2006) investigated the distribution of Trachurus japonicus larvae and juveniles in the ECS and revealed that most $T$. japonicus larvae are carried to the nursery grounds by the KC. Reiss and McConaugha (1999) found that fish spawned near the plume front and were subsequently transported offshore with the plume assemblage, suggesting the existence of a mechanism underlying the rapid cross-frontal transport of fish larvae in the inner continental shelf waters off the Chesapeake Bay. Sassa and Konishi (2015) observed that the northward intrusion of the Kuroshio transported mesopelagic fish larvae onto the continental shelf, but these larvae were distinctly separated from those of commercial species by the KF in the southern ECS. Overall, these studies have indicated that the intrusion of the Kuroshio may bring some fish species into these waters, but the KF between the shelf region and the eastern open ocean may nevertheless limit the spread of larvae.

Therefore, in the present study, we focused on several topics: (1) the changes of in hydrographic conditions on the southern ECS during the northeast monsoon season between November and March, especially with respect to the intrusion and recession of the KF, and the variation in upwelling at the confluence of the Kuroshio and CCC in the northern waters of Taiwan. We used field and satellite data captured during the northeast monsoon to assess changes in the KF and upwelling across the continental shelf waters of the southern ECS. (2) We collected ichthyoplankton samples from November to March to evaluate spatiotemporal changes in larvae abundance, composition, and assemblages in this area. Because rough sea conditions tend to hamper fieldwork in winter, previous studies have yielded limited information on larval fish assemblages, especially during 
the winter months. (3) Upwelling and the thermal front have opposing effects, with upwelling spreading larvae and the thermal front restricting such spread; hydrographic features may exert different effects on larval assemblages when upwelling and the thermal front are both present. Consequently, we investigated associations between larval fish communities and changes in the hydrographic environment to understand how thermal fronts and upwelling affect fish larval communities and their distributions. On the basis of our findings, we predicted that the abundance of mesopelagic species may be increased by the Kuroshio intrusion in winter; moreover, we predicted the fish assemblages would be most influenced by whichever-upwelling or the KF-was stronger when they occurred simultaneously. In addition, we also predicted if the KF was a barrier separating fish larvae assemblages, the mechanism underlying the cross- frontal transport of fish larvae would not occur, whether the species were neritic or oceanic

\section{METHODOLOGY}

All ichthyoplankton samples were obtained from the waters around the continental shelf in the southern ECS by the Ocean Research II vessel on 20 - 21 November 2012 (CR1914); 15 - 16 January 2013 (CR1918); 15 - 16 March 2013 (CR1923); and 16 - 17 March 2016 (CR2149) (Table 1). The data from 15 - 16 January 2013, and 15 16 March 2013, were obtained and modified from Wang et al. $(2013,2018)$. A total of 24 stations located between $25.2-25.45^{\circ} \mathrm{N}$ and $121.15-122.26^{\circ} \mathrm{E}$ were covered over four cruises (Fig. 1). We used the Ocean Research Institute net (University of Tokyo) for collection; the net had a

Table 1 . Summary of the coordinates of each sampling location, cruise number, date, fish larvae abundance (number/1000 $\left.\mathrm{m}^{3}\right)$, and number of fish eggs.

\begin{tabular}{c|c|c|cccc}
\hline \multirow{2}{*}{ Station } & \multirow{2}{*}{ Longitude $\left({ }^{\circ} \mathbf{E}\right)$} & \multirow{2}{*}{ Latitude $\left({ }^{\circ} \mathbf{N}\right)$} & \multicolumn{4}{|c}{ Abundance (Egg) } \\
\cline { 4 - 6 } & & & $\mathbf{C R 1 9 1 4}(\mathbf{2 0 1 2} / \mathbf{1 1})$ & $\mathbf{C R 1 9 1 8}(\mathbf{2 0 1 3} / \mathbf{0 1})$ & $\mathbf{C R 1 9 2 3}(\mathbf{2 0 1 3} / \mathbf{0 3})$ & $\mathbf{C R 2 1 4 9}(\mathbf{2 0 1 6} / \mathbf{0 3})$ \\
\hline st6 & 121.15 & 25.45 & $33(2)$ & $152(14)$ & $1959(1500)$ & $3294(212)$ \\
st7 & 121.29 & 25.39 & $16(19)$ & $155(91)$ & $6032(2246)$ & $145(49)$ \\
st8 & 121.43 & 25.35 & $216(115)$ & $172(74)$ & $688(517)$ & $3182(197)$ \\
st9 & 122.02 & 25.28 & $349(120)$ & $97(18)$ & $889(1620)$ & $1644(196)$ \\
st10 & 122.12 & 25.25 & $29(13)$ & $105(111)$ & $67(824)$ & $855(425)$ \\
st11 & 122.26 & 25.2 & $17(205)$ & $68(140)$ & $455(813)$ & $218(201)$ \\
\hline
\end{tabular}

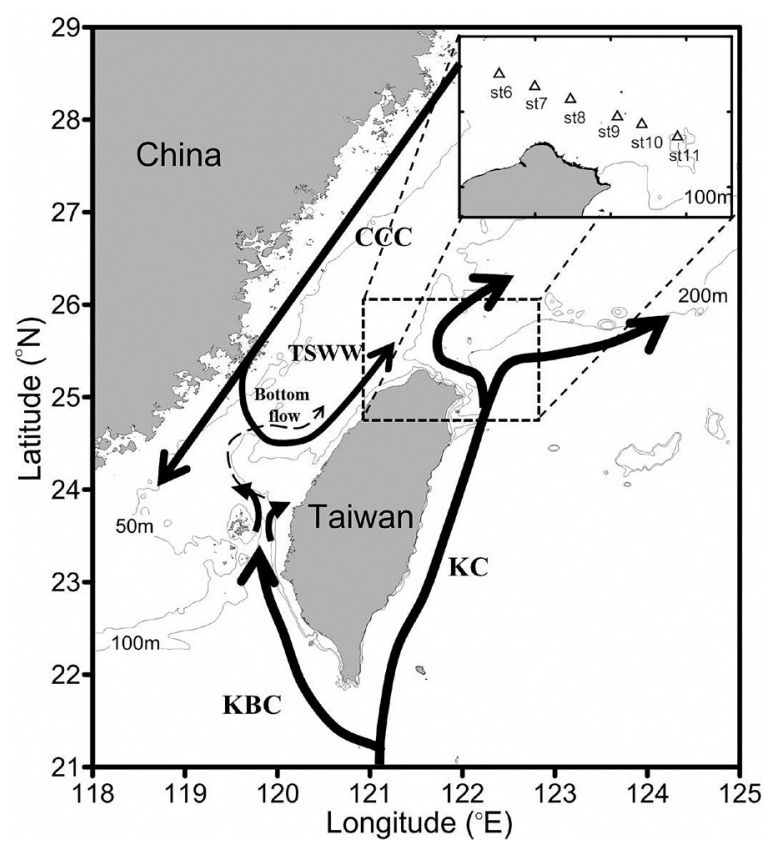

Fig. 1. Locations of sampling stations (hollow triangle) and schematic of the China Coastal Current (CCC), Taiwan Strait Warm Water (TSWW), Kuroshio Current (KC), and Kuroshio Branch Current (KBC) in the waters around Taiwan during the northeast monsoon (redrawn from Tang et al. 2000; Jan et al. 2002). 
mouth diameter of $1.6 \mathrm{~m}$ and mesh size of $330 \mu \mathrm{m}$ and was equipped with a digital flow meter (Model 438 115, HydroBios, Kiel-Holtenau, Germany) mounted at the center of the net mouth. At each station, the net was towed obliquely from a depth of $200 \mathrm{~m}$ or $5 \mathrm{~m}$ above the sea bed (when sea bed depth $<200 \mathrm{~m}$ ) to the sea surface at a speed of $1 \mathrm{~m} \mathrm{~s}^{-1}$.

All samples were preserved in a 70\% alcohol solution and brought to a laboratory. Larval fish were picked out from the samples and identified according to the descriptions in Okiyama (1988), as far as possible, up to the species level or the lowest possible taxonomic level. More than two fish in a family or genus were identified as many species (spp.). If the shape of a larval fish was broken, hampering identification, the fish was treated as an unknown species and not included in the data analysis.

Using morphological characteristics to identify fish species is challenging when their bodies are broken or when melanophores are unclear, especially in larvae. These problems may result from improper preservation or crushing during sample collection. According to Yukami et al. (2009) and Sassa and Tsukamoto (2010), the ECS is a habitat of the species Scomber japonicus and S. australasicus, both of which can be identified by their morphological characteristics, namely whether internal melanophores are present at the nape (body length $>7 \mathrm{~mm}$ ). In the present study, most Scomber spp. fish specimens were preflexion larvae in which the presence of internal melanophores at the nape could not be confirmed. We were unable to determine whether melanophores were absent or had not yet emerged, and we thus identified such specimens as Scomber spp. In particular, Diaphus A type had more postanal melanophores and were more slender than the B type. In the southern ECS, over 10 species of Diaphus are present (Wang and Chen 2001; Hsieh and Chiu 2002), and our study may thus have contained over 10 species. Other larvae classified under specific genera or families had no explicitly identifiable morphological characteristics; these included Apogonidae spp., Mugilidae spp., Myctophum spp., Stomias spp., and Saurida spp. Genetic techniques must be used to facilitate species identification and to uncover more detailed information on larval fish distribution.

Satellite data of monthly SSTs were obtained using Advanced Very High Resolution Radiometer sensors from the National Oceanic and Atmospheric Administration, analysis and processing in the Department of Environmental Biology and Fisheries Science, National Taiwan Ocean University. Temperature-salinity (T-S) diagrams and vertical profiles of water temperature and salinity were measured using a conductivity-temperature-depth profiler instrument (SBE 9/11, Sea-Bird Electronics Inc., Washington, D.C., USA) from the sea surface to a depth of $200 \mathrm{~m}$ (or near the sea bed at shallow stations); Surfer software (Version 9.11.947, Golden Software Inc., Golden, C.O., USA) was used to display diagrams and profiles.
Fish larvae abundance is expressed as the number of individuals (ind) per $1000 \mathrm{~m}^{3}$. The Shannon-Wiener diversity index (Shannon and Weaver 1963) and Pielou's index of evenness (Omori and Ikeda 1984) were used to calculate the diversity and evenness of species at each station. We used PRIMER 6 (Version 6.1.5, PRIMER-E Ltd, UK) and the Bray-Curtis index to calculate similarity among species compositions of larvae at the various sampling stations according to a similarity matrix of the natural logarithm abundance of larvae (Bray and Curtis 1957). The Bio-Env analysis was conducted in PRIMER 6 to investigate the Spearman's rank correlation (Q) between larval fish assemblages matrix (based on the Bray-Curtis similarity) and an environmental factors matrix (based on the Euclidean distance). The environmental factors included sea surface temperature (Ts) and sea surface salinity (Ss), sea bottom temperature (Ts), and sea bottom salinity (Sd) (depth of $200 \mathrm{~m}$ or $5 \mathrm{~m}$ above the sea bed in depths $<200 \mathrm{~m}$ ), chlorophyll a concentration, and the biomass of zooplankton (Clarke and Gorley 2006).

\section{RESULTS}

\subsection{Hydrographic Conditions}

Figure 2 presents a comparison of the T-S diagram of the study area is compared with the results of related studies (Gong et al. 1996; Chu et al. 2005; Jan et al. 2006). Temperature and salinity varied from 14.33 to $23.58^{\circ} \mathrm{C}$ and from 33.85 to $34.6 \mathrm{psu}$, respectively, indicating that all sampling stations were influenced by the TSWW on 20 - 21 November 2012 (Fig. 2a). On 15 - 16 January 2013, two major water masses were observed, namely the KC (stations 9 to 11 ) and the CCC (stations 6 to 8), where the temperature and salinity ranged from 15.56 to $25.23^{\circ} \mathrm{C}$ and from 33.65 to $34.88 \mathrm{psu}$, respectively (Fig. 2b). The CCC and TSWW were the major water masses affecting the hydrographic environment on 15 - 16 March 2013. Wider ranges of temperature and salinity were observed: 13.66 to $25.25^{\circ} \mathrm{C}$ and 33.11 to 34.67 psu, respectively (Fig. 2c). On 16 - 17 March 2016, the temperature and salinity were influenced by the CCC, $\mathrm{TSWW}$, and $\mathrm{KC}$; the temperature and salinity ranged from 13.42 to $21.85^{\circ} \mathrm{C}$ and from 34.09 to $34.61 \mathrm{psu}$, respectively (Fig. 2d). Relative to 2013, the temperature was lower and salinity was higher in 2016.

The vertical profiles of water temperature and salinity at the sampling stations during the study period are illustrated in Fig. 3. Stations 6 and 7 were dominated by warm $\left(>22^{\circ} \mathrm{C}\right)$ and fresh $(<34.2 \mathrm{psu})$ water, whereas upwelling water with a temperature of $<20^{\circ} \mathrm{C}$ and salinity of $>34.5$ psu was observed at stations 8 to 11 in November 2012. In January 2013, temperature and salinity at station 9 were $20^{\circ} \mathrm{C}$ and salinity of $>34.4 \mathrm{psu}$, respectively, indicating that the $\mathrm{KC}$ had reached it. An upwelling feature with a highsalinity tongue of $>34.6$ psu also appeared at station 9 . A 

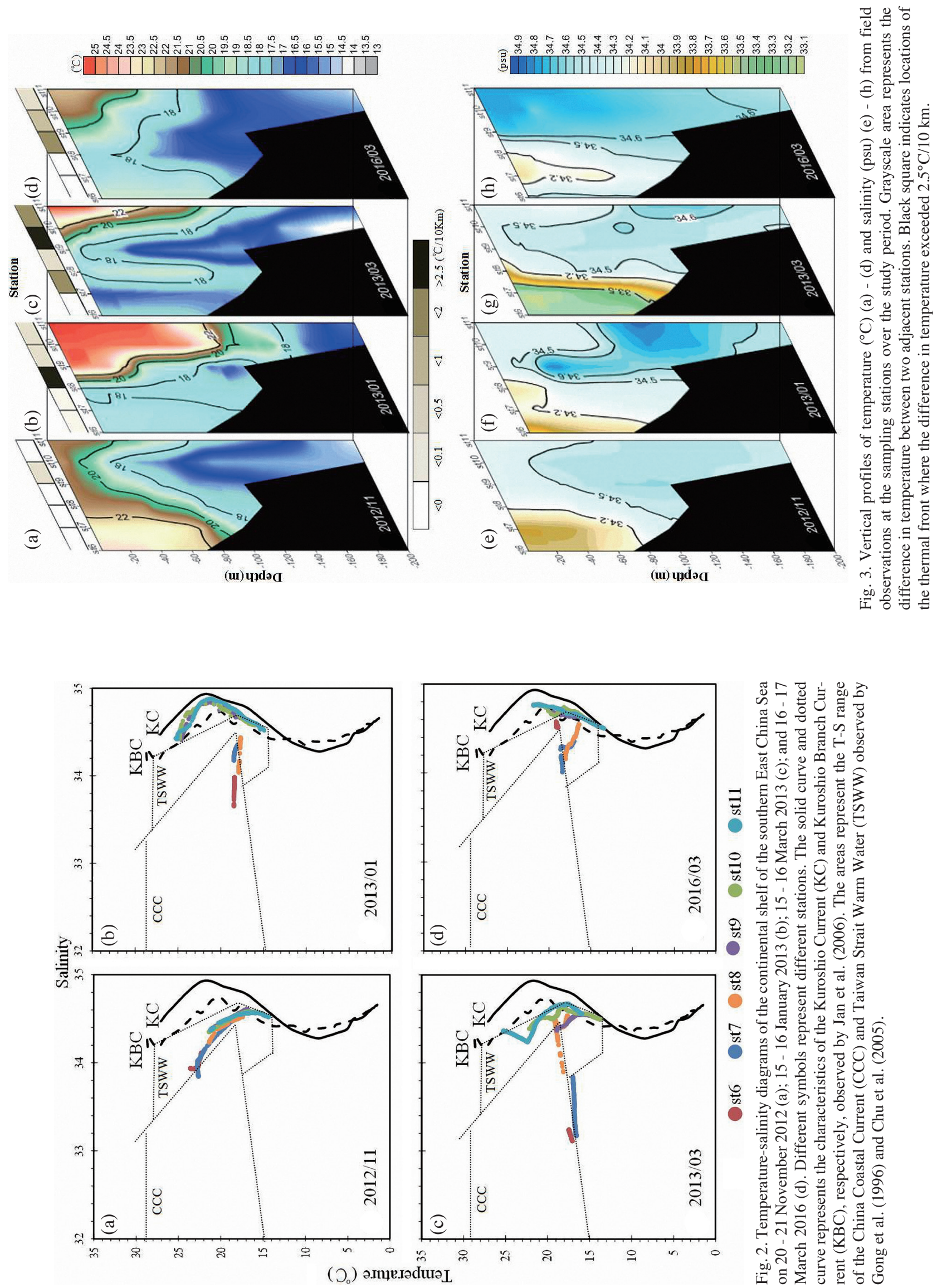

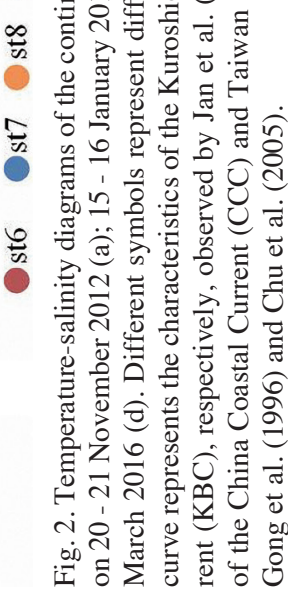


temperature gradient higher than $2.5^{\circ} \mathrm{C} / 10 \mathrm{~km}$ formed between the sea surface and a depth of $40 \mathrm{~m}$ between stations 8 and 9; this gradient then extended to the depths of $40-100$ $\mathrm{m}$ between stations 9 and 10 . The $\mathrm{KC}$ surface thermal front advanced to the area between stations 8 and 9 in January. In March 2013, the water at stations 6 and 7 had a low temperature $\left(<18^{\circ} \mathrm{C}\right)$ and low salinity $(<33.3 \mathrm{psu})$. The $\mathrm{KC}$ receded station 11, and strong upwelling occurred at station 9. In addition, a maximum SST gradient higher than $2.5^{\circ} \mathrm{C} / 10$ $\mathrm{km}$ shifted to the location between stations 9 and 10 . The hydrographic conditions in March 2016 differed from those of March 2013. At stations 10 and 11, the temperature was lower than in 2013. Upwelling water with high salinity was also not evident in 2016. Water with relatively low salinity (<34.2 psu) was observed between stations 7 and 8 .

Figure 4 illustrates the monthly satellite SST images, revealing the interaction between warm water $\left(>22^{\circ} \mathrm{C}\right)$ and cold water $\left(<20^{\circ} \mathrm{C}\right)$ during the study period. The strength of warm water was relatively low in western Taiwan but increased gradually in eastern Taiwan from November to Jan- uary. In February and March, warm water receded in eastern Taiwan, whereas that in western Taiwan slowly appeared. Warm water in eastern Taiwan was stronger in March 2013 than in March 2016.

\subsection{Changes in the Total Abundance of Larvae and Egg Number}

Overall, 9896 larval fish were collected, and unidentified species, most of which were injured or larvae at the yolk-sac stage, accounted for less than $10 \%$ of the total catch. Larval abundance varied, ranging from 16 to 349 ind/1000 $\mathrm{m}^{3}$ in November 2012, 68 to $172 \mathrm{ind} / 1000 \mathrm{~m}^{3}$ in January 2013, 67 to 6032 ind/1000 $\mathrm{m}^{3}$ in March 2013, and 145 to 3294 ind/1000 m³ in March 2016 (Table 1). According to the Kruskal-Wallis test $(p=0.0074)$, the abundance of fish larvae varied significantly among the four cruises. The spatial distribution of fish larvae abundance in November was the highest at stations 8 and 9. In January and March, abundance at the inner stations (6 to 8) was generally higher (a)
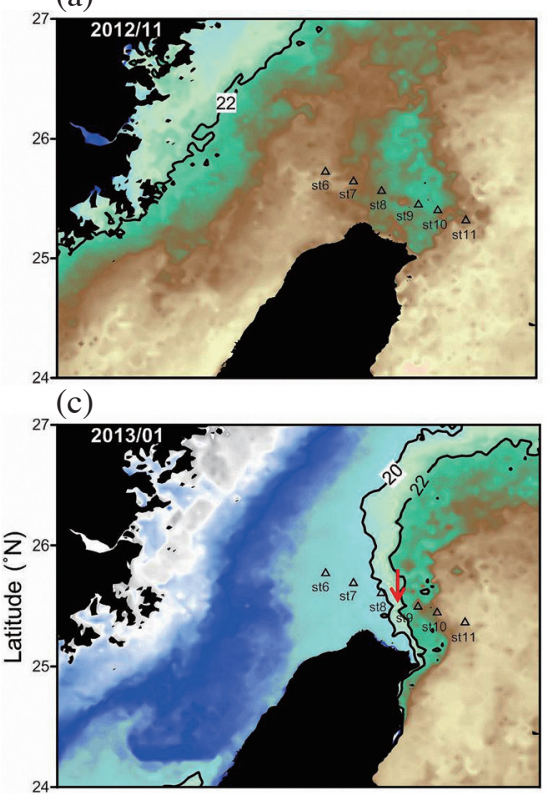

${ }_{27}(\mathrm{e})$

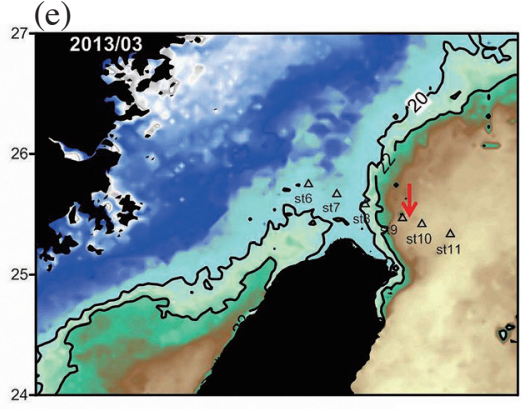

(b)

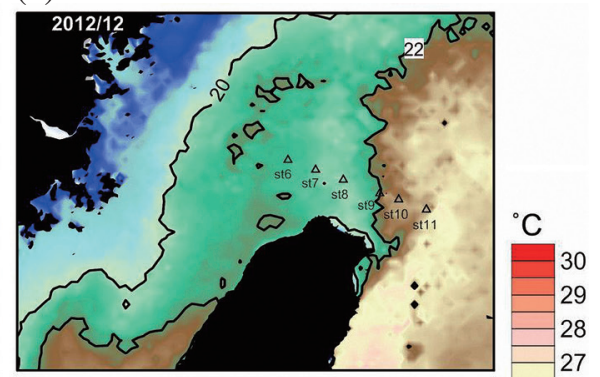

(d)

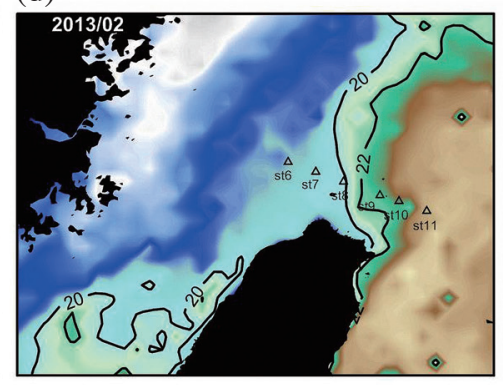

(f)

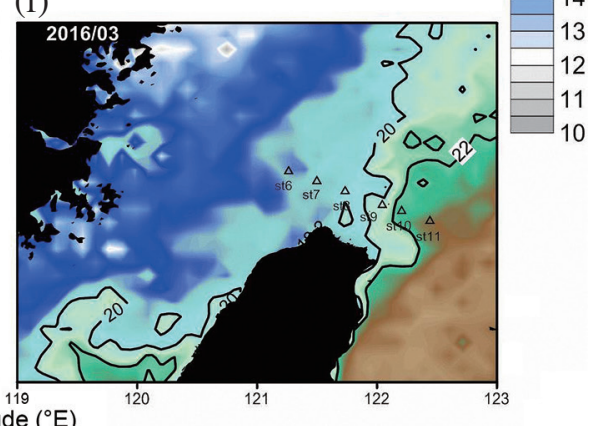

Fig. 4. Monthly satellite images of sea surface temperature in November 2012 (a); December 2012 (b); January 2013 (c); February 2013 (d); March 2013 (e); and March 2016 (f), in the southern East China Sea. Red arrows indicate the location of the Kuroshio Front (see Fig. 3). 
than that at the outer stations (9 to 11). In addition, 6139 fish eggs and 3683 anchovy eggs were collected in this study. Over $83 \%$ of the fish eggs and all of the anchovy eggs in the total catch were collected in March. The spatial distribution of fish eggs did not closely match that of fish larvae.

\subsection{Species Composition and Diversity}

Table 2 presents the species composition of fish larvae comprising over $1 \%$ of the total abundance for each cruise. Overall, 156 species in 83 families were identified over the four cruises in this study. The analysis of similarities (ANOSIM) test revealed a slightly significant difference in species composition over the four cruises $(R=0.39, p=0.001)$. The following six species were the most abundant and accounted for over 50\% of the total catch in November 2012: Sigmops gracile (22.84\%), Diaphus A type (9.08\%), Benthosema pterotum (7.17\%), Hime japonica (4.44\%), Engraulis japonicus (4.12\%), and Scopelarchus spp. (4.04\%). In January 2013, the eight most abundant species were Sebastiscus marmoratus (10.41\%), Trichiurus lepturus (10.31\%), Diaphus A type (7.22\%), Stomias spp. (5.72\%), B.pterotum (5.64\%), Diaphus B type (4.58\%), Saurida spp. (3.84\%), and Lampadena spp. (3.73\%), accounting for over $50 \%$ of the total catch. Engraulis japonicus was the most abundant species in March 2013 and March 2016, accounting for 80.29 and $43.23 \%$ of the total catch, respectively. The next most abundant species in these months were $T$. japonicus

Table 2. Species composition of larval fish comprising $>1 \%$ of the total catch from each cruise.

\begin{tabular}{|c|c|c|c|c|}
\hline Taxon $D$ Date & 2012/11 & 2013/01 & 2013/03 & 2016/03 \\
\hline Apogonidae spp. & 1.27 & 0.81 & 0.01 & \\
\hline Bathylagus spp. & 2.37 & 1.02 & 0.05 & 0.04 \\
\hline Benthodesmus spp. & 0.54 & 2.16 & 0.06 & 0.15 \\
\hline Benthosema pterotum & 7.17 & 5.64 & 0.71 & 0.25 \\
\hline Bregmaceros spp. & 3.02 & 2.86 & 0.06 & 0.10 \\
\hline Callionymidae spp. & 1.49 & 0.44 & 0.22 & 0.03 \\
\hline Champsodon spp. & 1.90 & & & \\
\hline Coryphaena hippurus & & 3.08 & 0.03 & \\
\hline Diaphus A group & 9.08 & 7.22 & 0.38 & 1.44 \\
\hline Diaphus B group & 2.98 & 4.58 & 0.43 & 0.73 \\
\hline Encrasicholina punctifer & & 1.56 & 0.18 & \\
\hline Engraulis japonicus & 4.12 & 2.76 & 80.29 & 43.23 \\
\hline Hime japonica & 4.44 & & 0.01 & 0.31 \\
\hline Lampadena spp. & 0.04 & 3.73 & & \\
\hline Maurolicus spp. & 2.69 & & & \\
\hline Moridae spp. & 2.53 & & & \\
\hline Myctophum spp. & 2.73 & 3.23 & 0.18 & 0.92 \\
\hline Pomacentridae spp. & & 1.69 & 0.04 & \\
\hline Saurida spp. & 0.63 & 3.84 & 0.78 & 1.47 \\
\hline Scomber spp. & & & 5.48 & 24.76 \\
\hline Scorpaenidae spp. & 0.54 & 3.02 & 0.10 & \\
\hline Scopelarchus spp. & 4.04 & 1.30 & 0.09 & 0.18 \\
\hline Sebastiscus marmoratus & 0.95 & 10.41 & 0.11 & 1.91 \\
\hline Sigmops gracile & 22.84 & 2.17 & 0.09 & 1.62 \\
\hline Stomias spp. & 0.15 & 5.72 & & 0.06 \\
\hline Trachurus japonicus & & & 5.57 & 15.13 \\
\hline Trichiurus lepturus & 3.90 & 10.31 & 0.18 & 0.72 \\
\hline Triglidae spp. & & 3.57 & 0.01 & \\
\hline Other fish species & 20.57 & 18.88 & 4.92 & 6.95 \\
\hline Sum & 100.00 & 100.00 & 100.00 & 100.00 \\
\hline
\end{tabular}


and Scomber spp., accounting for 5.57 and $5.48 \%$, respectively, in March 2013, and 15.13 and 24.76\%, respectively, in March 2016.

Figure 5 depicts the variations in diversity index and evenness index at the species level at each station. In November, the diversity index at station 8 was higher than those at the other stations. Furthermore, the diversity indices were lower at the inner stations (stations 6 and 7) but increased with station depth (stations 8 to 11) in January and March. The evenness index pattern in November differed from those in January and March. Relatively low evenness indices were recorded at station 9, whereas higher ones were recorded at stations 6 and 7; the average evenness indices were higher at station 9 to $11(0.91$ and 0.69$)$ than at station 6 to 8 (0.83 and 0.31) in January and March 2013. In addition, the results for March 2013 and March 2016 were evidently different.

\subsection{Species Assemblages Groups}

From the four cruises, three fish assemblages were divided according to a $10 \%$ similarity level using cluster analysis (Fig. 6). Stations 6 and 7 in November, and station 6 in January were grouped under an assemblage named the shelf mixed group, which included the neritic species of $B$. pteroutm, Saurida spp., T. lepterus, and Triglidae spp.; the oceanic species Lampadena spp. and Stomias spp. were characteristic of this group (Table 3). Other stations in November and January were grouped under an assemblage named the Kuroshio mixed group; the mesopelagic species $S$. gracile, Diaphus A type, and T. lepturus had low abundance and were thus characteristic of this group (Table 3). All stations in March 2013 and March 2016 were grouped under an assemblage named the coastal mixed group, which had high abundance dominated by the commercial and coastal species E. japonicus, Scomber spp., and T. japonicus (Table 3). Notably, cluster analysis revealed some spatial difference between the three groups.

We used cluster analysis to divide the five dominant species of each cruise into three groups, defined by according to a $70 \%$ similarity level (Fig. 6). These three groups could all be further divided into two subgroups with an $85 \%$ similarity level. The subgroup of the first group (1A) only contained Saurida spp., which was primarily observed in nearshore waters; subgroup 1B contained Stomias spp. and $H$. japonica, which were primarily observed at the offshore stations. Although these species differed in their distributions, they were all characterized by low abundance. The first subgroup of the second group (2A) contained two mesopelagic species, namely Diaphus A type and S. gracile, which were dominant at the offshore stations; subgroup 2B contained the coastal species $T$. lepturus, continental species $B$. pterotum, and $S$. marmoratus, which were primarily observed at nearshore stations. The species of the third group were abundant in March: E. japonicus was primarily observed between stations 6 and 7, whereas T. japonicus and Scomber spp. were commonly observed between stations 8 and 10 .

Figures 7a and $b$ illustrate the proportion of neritic and oceanic species at each station during November 2012 to March 2016 and during December 2006 to December 2009, respectively (Hsieh et al. 2007; Wang et al. 2013, 2018). The proportion of oceanic species was approximately average increase 10\% (46.2 - 79.6\%) from December to January and then decreased in March by approximately average decrease $50 \%(2.7-7.8 \%)$. Oceanic species were dominant (37.4 $86.5 \%$ ) in the oceanic waters on the offshore side of the KF, and some coastal and commercial species were dominant (26.9-99.1\%) in the neritic waters on the nearshore side of the KF from December to March. The abundance of oceanic species and neritic species differed between the offshore side and nearshore side of the KF.

\subsection{Fish Larvae and Hydrographic Structure}

The Bio-Env analysis revealed that various combinations of factors affected the larvae assemblages. Specifically, $\mathrm{Sd}$ and Ts were major factors during the study period
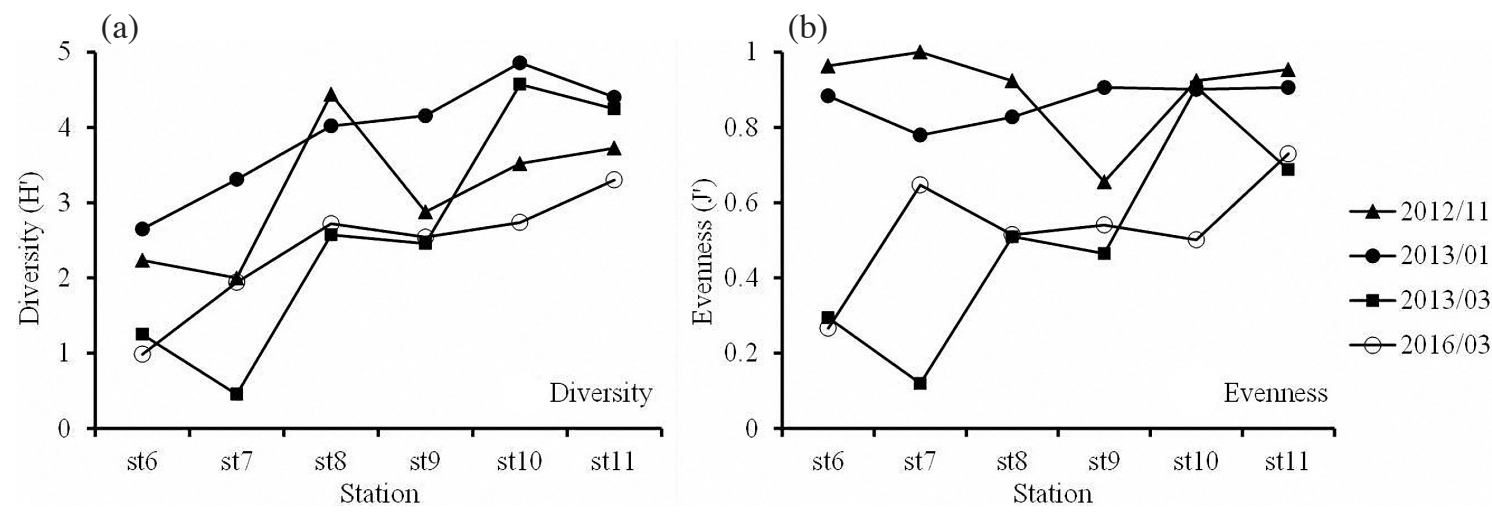

Fig. 5. Indices of diversity (H') (a) and evenness (J') (b) of fish larvae species at each station. 


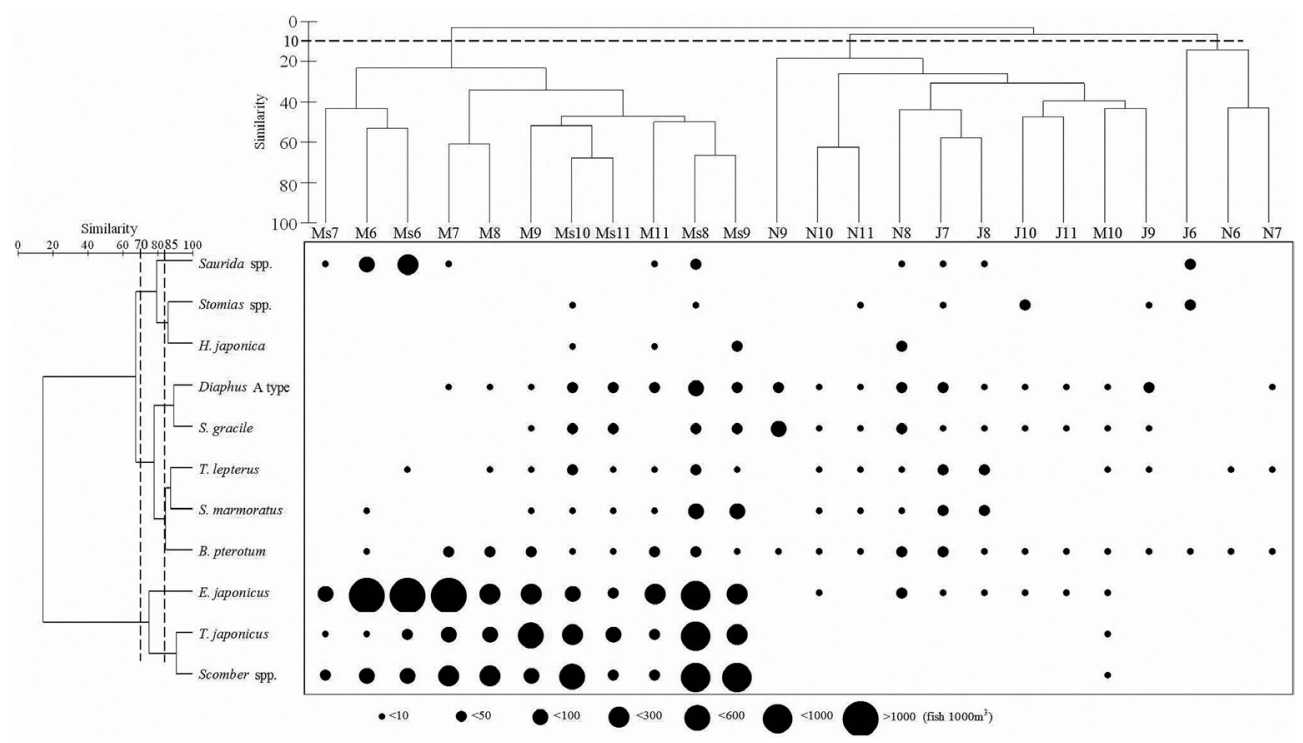

Fig. 6. Cluster analysis summary of the five dominant species of each cruise, with emphasis on the distribution of species groups within station groups. The solid circles represent the abundance of species groups in station groups. N, J, M, and Ms represent November 2012, January 2013, March 2013, and March 2016, respectively.

Table 3. Ten most abundant species of larval assemblages according to the cluster analysis results (see Fig. 6).

\begin{tabular}{|c|c|c|c|}
\hline Taxon & Shelf mixed Group & Kuroshio mixed Group & Coastal mixed Group \\
\hline Acropoma japonicum & 9.45 & & \\
\hline Benthosema pterotum & 12.80 & 56.25 & \\
\hline Bregmaceros spp. & 4.73 & 27.60 & \\
\hline Callionymidae spp. & 4.18 & & \\
\hline Diaphus A group & 4.18 & 83.72 & 167.36 \\
\hline Diaphus B group & & 42.21 & 109.19 \\
\hline Engraulis japonicus & & 36.77 & 11794.88 \\
\hline Lampadena spp. & 19.47 & 3.83 & \\
\hline Mugilidae spp. & & & 145.27 \\
\hline Myctophum spp. & & 32.79 & 101.10 \\
\hline Pseudolabrus eoethinus & 4.73 & 0.98 & \\
\hline Saurida spp. & 19.47 & & 209.97 \\
\hline Scomber spp. & & & 2783.41 \\
\hline Scopelarchus spp. & & 27.33 & \\
\hline Sebastiscus marmoratus & & 67.58 & 184.33 \\
\hline Sigmops gracile & & 124.46 & 155.13 \\
\hline Stomias spp. & 19.47 & 15.86 & 5.66 \\
\hline Trachurus japonicus & & & 1918.94 \\
\hline Trichiurus lepturus & 13.63 & 67.71 & \\
\hline Triglidae ssp. & 19.47 & & 3.72 \\
\hline Other larval fishes & 11.66 & 362.80 & 1297.27 \\
\hline Sum & 143.24 & 949.89 & 18876.23 \\
\hline
\end{tabular}



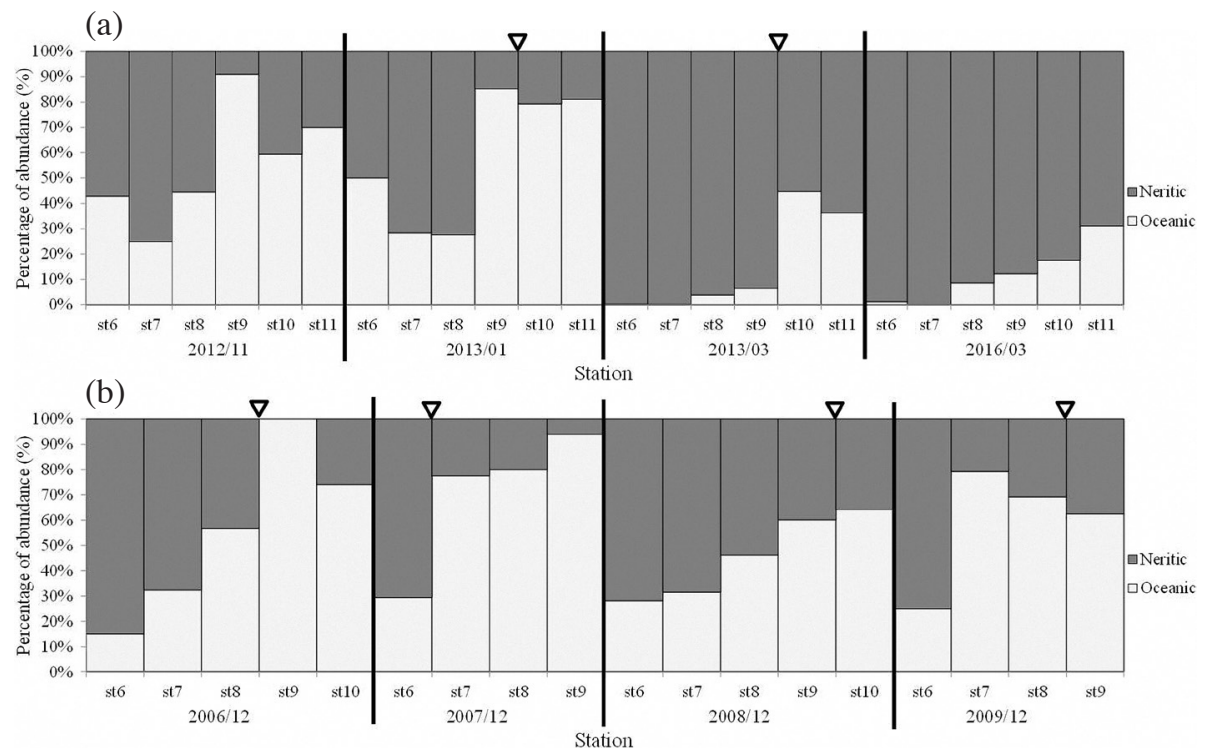

Fig. 7. Proportion of neritic and oceanic species at each station from November 2012 to March 2016 (a) and December 2006 to December 2009 (b) (redrawn from Wang et al. 2013, 2018). Triangles indicate the locations of the Kuroshio Front (see Fig. 3) where the difference in temperature exceeded $2.5^{\circ} \mathrm{C} / 10 \mathrm{~km}$ (a) and $1.5^{\circ} \mathrm{C} / 10 \mathrm{~km}(\mathrm{~b})$ (redrawn from Wang et al. 2013, 2018).

(Table 4). When upwelling was clear and strong, such as in November 2012, Sd was the most crucial factor, whereas Ts became a major factor when the KF was strong and upwelling was weak in January 2013 (Tables 4a and b). The results for March 2013 revealed different combinations of factors when the KF and upwelling occurred simultaneously (Table 4c). In March 2013, the upwelling was strong and the KF occurred; thus, Sd was the main factor affecting larvae assemblages. In March 2016, whether the KF and upwelling occurred was unclear, and determining the combinations of primary factors was thus more complicated relative to that in other months (Table 4d).

\section{DISCUSSION}

\subsection{Upwelling and Thermal Front Shift in the KC}

The upwelling of the Kuroshio subsurface water in northeastern Taiwan, which is a year-round phenomenon, results from the impingement of the Kuroshio onto the continental shelf (Liu et al. 1992). It has been observed in field surveys (Tang et al. 2000), satellite remote sensing studies (Lin et al. 1992; Cheng et al. 2009), and numerical studies (Wu et al. 2008). In November 2012, a cold dome with a central SST of approximately $22^{\circ} \mathrm{C}$ was clearly observed through satellite SST images because the KC did not enter this water. However, identification of this upwelling phenomenon on an SST map between January and March is difficult because the $\mathrm{KC}$ enters and because the $\mathrm{KF}$ forms on the continental shelf of the southern ECS during this period. According to Jan et al. (2011), upwelling waters are cold $\left(<21^{\circ} \mathrm{C}\right)$ and salty $(>34.5 \mathrm{psu})$ and are upwelled along the continental slope northeast of Taiwan. Our results revealed a dome of subsurface waters, with a low temperature and high salinity, that frequently appeared at station 9 on the continental shelf of the ECS. This finding is similar to the hydrographic features observed in related studies. Wu et al. (2008) demonstrated that the occurrence of upwelling is associated with the zonal migration of the Kuroshio northeast of Taiwan. The seasonal migration of the Kuroshio generally involves a shift away from the shelf in summer-when the upwelling waters are evident and easy to observe-and a shift closer to the shelf in winter-when the upwelling waters are inhibited (Liu et al. 1992; Tang et al. 2000; Liang et al. 2003; Oey et al. 2010). Wang et al. $(2013,2018)$ described the upwelling in waters deeper than $40 \mathrm{~m}$ in December from 2006 to 2009 . The upwelling depths reported by these authors have varied through the years, but they were all deeper than those observed in November 2012. In summary, the aforementioned findings are consistent with the hydrographic features we observed between November and March (Figs. 3 and 4). We found that the intensity of upwelling waters changed over time: it was strong in November, weaker in December and January, and then became stronger again in March during the northeast monsoon.

We observed the formation of a clear KF on the continental shelf of the southern ECS on satellite SST maps for January to March 2013 (Figs. 4c - e). According to the vertical profiles of temperature results (Figs. $3 b$ and c), a KF with a maximum SST gradient of more than $2.5^{\circ} \mathrm{C} / 10 \mathrm{~km}$ formed at nearshore stations 8 and 9 in January and then shifted seaward to between stations 9 and 10 in March. These observations are consistent with those of Chang et al. 
Table 4. Spearman's rank correlations $(\rho)$ among larval assemblages and monthly environmental factor resemblance matrices obtained through the Bio-Env analysis. The data from December 2006 to December 2009 were a reanalysis of those reported by Wang et al. (2013, 2018). Sd, sea bottom salinity (psu); Ss, sea surface salinity (psu); Td, sea bottom temperature $\left({ }^{\circ} \mathrm{C}\right)$; $\mathrm{Ts}$, sea surface temperature $\left({ }^{\circ} \mathrm{C}\right)$.

(a) November 2012

\begin{tabular}{ccc}
\hline Number of variables & Best variable combinations & Correlation (@) \\
\hline 1 & Sd & 0.589 \\
2 & Ss & 0.493 \\
\hline
\end{tabular}

(b) January 2013

\begin{tabular}{ccc}
\hline Number of variables & Best variable combinations & Correlation (o) \\
\hline 1 & Ts & 0.857 \\
1 & $\mathrm{Sd}$ & 0.846 \\
\hline
\end{tabular}

(c) March 2013

\begin{tabular}{ccc}
\hline Number of variables & Best variable combinations & Correlation (@) \\
\hline 1 & $\mathrm{Sd}$ & 0.579 \\
2 & $\mathrm{Ts}, \mathrm{Sd}$ & 0.514 \\
\hline \multicolumn{4}{c}{ Number of variables } & Best variable combinations & Correlation (@) \\
\hline 3 & $\mathrm{Ss}, \mathrm{Td}, \mathrm{Sd}$ & 0.415 \\
2 & $\mathrm{Sd}$ & 0.402 \\
\hline
\end{tabular}

(e) December 2006

\begin{tabular}{ccc}
\hline Number of variables & Best variable combinations & Correlation (@) \\
\hline 2 & Sd, Ts & 0.574 \\
1 & Ss & 0.427 \\
\hline
\end{tabular}

(f) December 2007

\begin{tabular}{ccc}
\hline Number of variables & Best variable combinations & Correlation (@) \\
\hline 1 & $\mathrm{Ts}$ & 0.867 \\
1 & $\mathrm{Sd}$ & 0.827 \\
\hline
\end{tabular}

(g) December 2008

\begin{tabular}{ccc}
\hline Number of variables & Best variable combinations & Correlation (@) \\
\hline 3 & Ts, Sd & 0.527 \\
2 & Ts & 0.467 \\
\hline
\end{tabular}

(h) December 2009

Number of variables Best variable combinations Correlation (@)

$\begin{array}{ccc}2 & \text { Sd, Ts } & 0.515 \\ 1 & \text { Sd } & 0.424\end{array}$

(2008) and Wang et al. $(2013,2018)$ that a warm frontal band tends to occur at approximately 100-m isobaths as the KC migrates shoreward during winter. Wang et al. (2013) reported that the KF shifted between stations 6 and 10 from 2006 to 2009 but often appeared between stations 9 and 10 . The location of the KF varied over time: it was observed between stations 9 and 10 in December, then intruded to stations 8 and 9 in January, and subsequently retreated to stations 9 and 10 in March (Wang et al. 2018). Cheng et al. (2009) also reported that the KF approached the shelf in winter and retreated after spring. Thus, we infer that the KF appears between December and March on the continental shelf of the southern ECS during the northeast monsoon: it starts to intrude from December to January and then retreats from February to March. Moreover, we observed a cold front $\left(<1^{\circ} \mathrm{C} / 10 \mathrm{~km}\right)$ between stations 6 and 7 in March 2013. Similar findings were reported by Chang et al. (2008), who suggested that a cold front appears at the inshore edge of the 100-m isobaths. This co-occurrence of cold and warm fronts suggest strong coupling between intrusion and upwelling in the shelf region in winter.

Oey et al. (2010) noted that cold surface temperatures may hinder the identification of the upwelling feature because the $\mathrm{KC}$ tends to be strong and close to the continental shelf of the southern ECS in the winter. Therefore, it is crucial to consider the interaction mechanisms of the KF and upwelling. Upwelling and KF coexist during the northeast monsoon; however, when the KF intrudes strongly into the continental shelf of the southern ECS, it restrains the upwelling. Another notable observation of the present study is that no dome of subsurface waters with high salinity was found in March 2016. High-salinity waters appeared to be present only in the surface layer. The monthly satellite SST images indicated interaction between the $\mathrm{CCC}, \mathrm{KC}$, and TSWW (Fig. 4). In 2016, the KC was farther from the continental shelf than it had been in 2013 (Figs. 4e and f). In addition, the weak, offshore $\mathrm{KC}$ may have influenced the location of the upwelling waters; however, we had insufficient data to verify this.

\subsection{Temporal Variation in Species Composition Structure}

The dominant species in March 2013 and March 2016 (namely, E.japonicus, T. japonicus, and Scomber spp.) differed significantly from those in November 2012 (namely, $S$. gracile, Diaphus A type, and B. pterotum) and from those in January 2013 (namely, S. marmoratus, T. lepturus, and Diaphus A type). These significant differences in species composition, as revealed by the ANOSIM test, suggests that ichthyoplankton composition varies by month, with the most significant variation observed in March.

The ECS continental shelf is considered a key migration route for several commercially important fish, including Japanese anchovy (E.japonicus), mackerel (S. australasicus and S. japonicus), and swordtip squid (Loligo edulis) (Chen and Chiu 2003; Hsieh et al. 2007). In the present study, the abundance of E. japonicus larvae in November 2012 and January 2013 was low; however, it was significantly dominant and comprised approximately $16-57 \%$ of all samples 
at stations 6 and 7 where the boundary region of the CCC and KC had formed at the continental shelf in March 2013 (Table 2; Fig. 6). Tu et al. (2012) developed a coupled hydrodynamic fish behavior model to investigate the effects of the physical environment on the migration of E. japonicus. The researchers suggested that the spawning migration of E. japonicus from the ECS to Taiwan may be aided by the CCC and the species' swimming velocity; orientation toward favorable spawning grounds is crucial during spawning migration. Chen and Chiu (2003) used local flow patterns and SST images to further demonstrate that anchovy larvae are transported from offshore to coastal areas alongside an identified coastal current in the waters northeast of Taiwan. Notably, in the present study, more E. japonicus larvae were observed in March 2013 than in 2016 and, according to the T-S diagrams, the effect of the CCC was stronger in March 2013 than in March 2016 (Figs. 2c and d). Hsieh et al. (2009) indicated that variation in larval anchovy abundance is determined by El Niño signals. The researchers further demonstrated that a decline in larval anchovy abundance during El Niño-Southern Oscillation events may have been due to a weaker CCC. These findings support our finding that the CCC is a key facilitator of spawning migration among E.japonicus.

Trachurus japonicus and Scomber spp. were the two dominant species in March in the present study. Trachurus japonicus spawns from January to June, especially in abundance from February to March (Sassa et al. 2006), and is the main target species of commercial fisheries in the traditional fishing ground of the ECS (Tzeng 1984). In our study, this species frequently appeared at station 9 in the upwelling zone with a water temperature of $17-22^{\circ} \mathrm{C}$ (Fig. 3). This temperature range is near the optimal spawning range of $20-23^{\circ} \mathrm{C}$ reported by Ochiai et al. (1983). Scomber spp. includes only $S$. australasicus and $S$. japonicus in Taiwan waters, both of which generally begin maturation in January and spawn from February to March (Bolanos and Tzeng 1994). Tzeng (1984) indicated that S. australasicus was the dominant species in Taiwan's purse seine fishery in the early 1980s. From 1981 to 1986, the oceanic environment in the coastal waters of Taiwan was more suitable for the growth of S. australasicus than for that of S. japonicus (Bolanos and Tzeng 1994). However, in warm waters of $29-31^{\circ} \mathrm{C}$, the appearance rate of juvenile $S$. japonicus was high in the catch of Taiwan's purse seine fishery. By contrast, the appearance of juvenile S. australasicus was rare from 1995 to 1997. Thus, Hsieh et al. (2007) suggested that variations in S. australasicus and S. japonicus stocks may have interacted and were governed by natural causes as opposed to fishing activity. In the current study, we observed annual density variations in Scomber spp. and T. japonicus. The density percentages of Scomber spp. and T. japonicus increased and decreased, respectively, during 2013 - 2016. Hsieh et al. (2007) and Sassa and Tsukamoto (2010) have indicated that $S$. australasicus are abundant in the southern ECS in February and March; the optimal temperature range for this species is $17-25^{\circ} \mathrm{C}$ (Yukami et al. 2009), whereas that of $T$. japonicus is slightly lower at $17-23^{\circ} \mathrm{C}$ (Ochiai et al. 1983; Hsieh et al. 2007). Because of the weak CCC in March 2013, the average SST was higher in March 2016 than in March 2013. Accordingly, we argue that the annual density variations in these species are due to temperature.

Sassa and Kawaguchi (2006) indicated that $S$. gracile is a dominant species in Kuroshio water and that the species is observed more frequently in cold periods than in warm periods (Lo et al. 2010; Hsieh et al. 2011; Su et al. 2011). In the present study, this species was found not only in November but also in January and March. Because T-S diagrams indicated that the effect of the Kuroshio was stronger in January than in November, the density of $S$. gracile should have been higher in January than in the other months (Fig. 2); however, the density of S. gracile was higher in November than in January and March, possibly because the spawning season of $S$. gracile occurs from October to December (Sassa and Hirota 2013). In addition, Bathylagidae, Sternoptychidae, Phosichthyidae, and Myctophidae are key fish communities in the Kuroshio waters (Sassa et al. 2004a, c, 2007). In our results, the abundance of $S$. gracile and other mesopelagic fish (including Diaphus B type, Stomias spp., and Lampadena spp.) respectively decreased and increased during November to January; a greater number of species from November to January may indicate that these mesopelagic fish are brought by the Kuroshio in January. Therefore, S. gracile and other mesopelagic fish may have a competitive relationship in Kuroshio waters, leading to the lower abundance of $S$. gracile compared with other mesopelagic fish. This may explain why $S$. gracile was dominant in November-in contrast to the other mesopelagic fish, which we observed to be dominant in January. Other species, namely Saurida spp., S. marmoratus, and T. lepturus, have long spawning periods and are most abundant in winter (Rao 1983; Takano et al. 1991; Yoneda et al. 2002); this finding corresponds with those of Hsieh et al. (2007), Lo et al. (2010), and Wang et al. (2013).

The dominant species in December from 2006 to 2009 were similar and included the following, by year: $B$. pterotum, Diaphus B type, and Bregmaceros spp. in 2006; S. gracile, T. lepturus, and Bregmaceros spp. in 2007; Apodonidae spp., Scomber spp., and Diaphus B type in 2008; and Myctophum obtusirostre, S. gracile, and Diaphus A type in 2009 (Wang et al. 2013, 2018). These species belong to mesopelagic fish, but some species are pelagic and coastal fish. When the KC starts intruding into the continental shelf of the southern ECS in December, it may bring these mesopelagic fish into the area (Lo et al. 2010). However, the abundance of some species varied by year, which are attributable to annual environmental changes. Sigmops gracile was more abundant in 2007 than in other years 
possibly because the effect of the Kuroshio was stronger in that year and therefore brought more of this species. In 2006 and 2008, the effect of the Kuroshio was weaker, which led to decreases in mesopelagic fish and increases in some coastal fish species (such as B. pterotum, Bregmaceros spp., Scomber spp., and Apogonidae spp.). This finding corresponds with those of Sassa and Konishi (2015) and Chen et al. (2016). However, we observed that the variation in dominant species during the northeast monsoon period occurred close to the spawning season of adult fish; therefore, the abundance of larvae may be affected by the intensity of intrusion of the $\mathrm{CCC}$ and $\mathrm{KC}$.

\subsection{Larval Assemblages in Relation to the KF and Upwelling}

In contrast to adult fish, larval fish are pelagic plankton, which have multiple ecological roles (Leis 2006). Most relevant studies have indicated that larval assemblages are influenced by thermal fronts, salinity fronts, chlorophyll fronts, and eddies (Hsu et al. 1998; Sassa et al. 2004b; Bakun 2006; Franco et al. 2006; Danell-Jiménez et al. 2009). According to our results, we propose that larvae assemblages are associated with both upwelling and the thermal front. Strong upwelling frequently occurs in the southern ESC during early winter, and such upwelling affected fish assemblages in November 2012 (Table 4a). On the basis of our cluster analysis results (Fig. 6), larval fish assemblages were divided into groups based on the location of the upwelling. In the strong upwelling period (November), most of the neritic species larvae remain close to shore, indicating that the upwelling waters may concentrate coastal larvae in nearshore regions, this proposition accords with Morgan et al. (2009). Upwelling resulted in less neritic larval dispersal to offshore regions, which may have contributed to increases in feeding and survival. Some mesopelagic fish may also spread and remain close to the nutritious coastal waters due to upwelling transportation.

In December, the upwelling is weaker when the KF appears (Wang et al. 2013, 2018). As evident in the results of this study and Wang et al. (2013), the KF begins to appear in December, extends to approximately $121.7^{\circ} \mathrm{N}$ in January and then shifts seaward to approximately $122.1^{\circ} \mathrm{N}$ in March. The strong KF that occurred in December 2007 and January 2013 became a main factor affecting fish assemblages (Tables 4b and f). Okazaki and Nakata (2007) indicated that the Kuroshio frontal eddy may be a crucial factor influencing larval distribution in the frontal region of the southern ECS. Sassa and Konishi (2015) also reported that the KF is a major determinant of the distributions of mesopelagic fish larvae in waters near central and southern Japan. The abundance of oceanic and neritic species differed between the offshore side and nearshore side of the KF (Fig. 7). Studies have found that larval assemblages have invariably been divided into two categories, namely Taiwan Strait/mixed shelf assemblages (left side of the KF) and Kuroshio assemblages (right side of the KF; Table 5). The Taiwan Strait/mixed shelf assemblage mainly comprises coastal and neritic species-including E.japonicus, Saurida spp., T. lepturus, and Bregmaceros spp. - whereas the dominant species in the Kuroshio assemblage include oceanic species - namely $S$. gracile, Diaphus spp., and Stomias spp. These results indicate that the mesopelagic species may be separated from the neritic species by the KF (Sassa and Konishi 2015).

In addition, the spatial distributions of the Taiwan Strait/mixed shelf and Kuroshio assemblages vary; the distributions also shift slightly shoreward or seaward with the intrusion or recession of the KF, respectively. Wang et al. (2013) described variations, over a 4-year period in wintertime fish-larvae assemblages associated with the KF on the continental shelf of the southern ECS. Myctophids and gonostomatids - such as S. gracile, Diaphus spp., and Myctophum spp. - were dominant on the oceanic side of the KF. Some coastal and commercial species were dominant on the

Table 5. Comparison between the larval fish compositions on the left and right sides of the Kuroshio Front on the continental shelf of the southern East China Sea during the northeast monsoon period, as reported in previous literature and the present study.

\begin{tabular}{|c|c|c|c|c|}
\hline \multirow{2}{*}{\multicolumn{2}{|c|}{ Date }} & \multicolumn{2}{|c|}{ Dominant species } & \multirow{2}{*}{ References } \\
\hline & & \multirow{2}{*}{$\begin{array}{l}\text { Left side / Nearshore side Taiwan Strait / Mixed shelf } \\
\text { B. pterotum, E. japonicus, Diaphus B type, Serridae spp. }\end{array}$} & \multirow{2}{*}{$\begin{array}{c}\text { Right side / Offshore side Kuroshio } \\
\text { Bregmaceros spp., Diaphus B type, } \text { M. orientale }\end{array}$} & \\
\hline \multirow{4}{*}{ December } & 2006 & & & \multirow{4}{*}{$\begin{array}{l}\text { Wang et al. (2013, } \\
\text { 2018) }\end{array}$} \\
\hline & 2007 & & S. gracile, T. lepturtus, Callionymidae spp. & \\
\hline & 2008 & $\begin{array}{c}\text { Apogonidae spp., Scomber spp., Diaphus B type, } \\
\text { B.pterotm }\end{array}$ & $\begin{array}{c}\text { Diaphus A type, E. punctifer, M. obtusirostre, } \\
\text { S. gracilis }\end{array}$ & \\
\hline & 2009 & Saurida spp., T. lepturus & $\begin{array}{l}\text { M. obtusirostre, S. gracilis, Diaphus A type, } \\
\text { Myctophum spp. }\end{array}$ & \\
\hline January & 2013 & S. marmoratus, T. lepterus, B. pterotum & Diaphus A type, Myctophum spp., Stomias spp. & Wang et al. (2018) \\
\hline \multirow{2}{*}{ March } & 2005 & Scomber spp., T. japonicus, M. asperum & & \multirow{2}{*}{$\begin{array}{l}\text { Hsieh et al. (2007); } \\
\text { Wang et al. (2018); } \\
\text { this study }\end{array}$} \\
\hline & 2013 & E. japonicus, T. japonicus, Scomber spp. & E. japonicus, Diaphus B type, T. japonicus & \\
\hline
\end{tabular}


neritic side of the $\mathrm{KF}$, where the waters were more influenced by the CCC than by the KC. In the Kuroshio assemblage, some species of Myctophidae and Gonostomatidae have been used as indicator species of the $\mathrm{KC}$ because they are found primarily in the $\mathrm{KC}$ and adjacent areas (Hsieh et al. 2010). According to Sassa et al. (2006), the Kuroshio carries the fish larvae of jack mackerel northeastward to reach the Pacific coast of southern Japan - they inferred this on the basis of the abundance of these larvae in the Kuroshio frontal area along the shelf break (Uehara and Mitani 2002). Sassa and Konishi (2015) also determined that a northward intrusion of the Kuroshio transports mesopelagic fish larvae onto the shelf in the southern ECS because these fish larvae were more abundant in the waters of the Kuroshio than in other waters.

Chen et al. (2016) defined the frontal area as the boundary past which the mesopelagic fish larvae of the $\mathrm{KC}$ tend not to intrude intruding into the waters of northern Taiwan; the boundary was defined as such because these fish were more abundant on the right side of the KC. The aforementioned findings correspond with our findings that most neritic species are more abundant in nearshore waters than in offshore waters and that oceanic species are more abundant in offshore waters than in nearshore waters. The Kuroshio waters bring some oceanic species into nearshore waters from offshore waters, and consequently, the abundance of the Kuroshio assemblage species is strongly related to the intrusion intensity of the $\mathrm{KC}$.

A variation in fish larval distribution by upwelling and the thermal front was identified in December 2006, December 2008, December 2009, and March 2013 (Wang et al. 2013). According to both our results and previous studies (Wang et al 2013,2018), Sd and Ts were two major factors affecting the fish assemblages, but $\mathrm{Sd}$ had a greater effect in December 2006, December 2009, and March 2013; Ts had a greater effect in December 2008 (Table 4). The Bio-Env results for December 2006, December 2009, and March 2013 were similar to those for November 2012 because the upwelling was strong; the results for December 2007 and 2008 were similar to those of January because the KF was strong. Therefore, we suggest that when the KF and upwelling occur simultaneously, the stronger one will has the greater effect on fish assemblages.

\subsection{Mechanism Underlying the Cross-KF Transport of Fish Larvae}

Studies have typically contended that the front was a barrier separating coastal and oceanic fish larvae, with the distribution of larval fish reflecting not only hydrographic conditions but also the habitats or spawning habits of adults (Sabatés 1990). Species such as Stomias spp. and S. gracile inhabit deep oceanic waters and exhibit major spawning behavior there (Butler et al. 2001; Sassa and Kawaguchi
2006); in addition, these species are abundant in offshore waters. Saurida spp., H. japonica, and S. marmoratus feed and spawn in coastal waters (Rao 1983; Tzeng et al. 1997; Yoneda et al. 2002). Trachurus japonicus and Scomber spp. are mostly distributed in mixed waters (Hsieh et al. 2007; Sassa et al. 2008b); we collected these species between coastal and oceanic waters. Benthosema pterotum, E. japonicus, and T. lepturus are widely distributed, but they primarily inhabit and spawn in shelf waters (Iseki and Kiyomoto 1997; Martins and Haimovici 1997; Chen and Chiu 2003; Kim et al. 2005; Wang et al. 2006; Lee et al. 2013; Sassa et al. 2010). The spawning ground of Diaphus A type may vary because this type comprises several species. Ohshimo et al. (2012) reported that three pseudoceanic species (D. garmani, D. chrysorhynchus, and D. watasei) in this genus are widely distributed throughout the continental shelf and slope regions. Moku et al. (2003) noted that the spawning ground of $D$. theta is in the transitional waters between the Oyashio Front and KF. Castro et al. (2010) found that $D$. splendidus is distributed in warm and oceanic waters. The aforementioned studies have all noted that these species have diverse spawning grounds, which potentially explains their wide distribution.

Sabatés and Olivar (1996), however, claimed that the front does not act as a barrier separating the larval distributions of shelf and oceanic species but rather limits the extent of the larval distribution of shelf species. If the KF was a barrier separating fish larvae assemblages, the mechanism underlying the cross-frontal transport of fish larvae would not occur, whether the species were neritic or oceanic, meaning that the nearshore side of the front would not collect the oceanic fish species and the offshore side of the front would also not collect the coastal fish species. However, in our results, we observed some neritic species and oceanic species on the right side and left side of KF, respectively (Fig. 7). More oceanic species were present on the nearshore side compared with the number of neritic species on the offshore side even when the KF was strong in January or upwelling was strong in December. The KF is accompanied by the interaction of KC shoreward intrusions and mixing shelf water flowing in from the Taiwan Strait or $\mathrm{CCC}$; thus, the KF generation may result in the cross-frontal transport of marine organisms and larval fish in the study area (Sassa et al. 2008b; Sassa and Konishi 2015; Chen et al. 2016). We infer that the mechanism underlying the cross-KF transport of fish larvae was more intense for oceanic than for neritic species. Because they exhibit vertical migration behavior (Watanabe et al. 1999), Danell-Jiménez et al. (2009) contended that those mesopelagic larvae may also possibly cross the pycnocline. The movement of larvae of mesopelagic species through the water column has also been observed in the vertical distribution of fish larvae, as reported in the studies of Loeb and Nichols (1984) and Moser and Smith (1993). Tiedemann and Brehmer (2017) 
also indicated that some species with vertical migration behavior may be able to avoid transport to disadvantageous waters by actively descending to deep layers. Consequently, oceanic species may more easily cross the front than neritic species, thus demonstrating that the barrier effect of the $\mathrm{KF}$, and consequent separation has a greater effect on neritic species. In March, the upwelling was stronger than the KF, and the coastal and neritic species were spawning and dominant in the southern ECS. These fish can spread to and through the nutritious waters as a result of the strong upwelling. However, the probability of cross-KF transport of oceanic fish larvae in order to spawning, feeding, growing, or hiding from predation may have been increased when the front was weakened; the abundance of these species should be increased in the nearshore water. In this study, the abundance of oceanic species was not increased in the nearshore water in March may be to avoid the competition for food with the neritic species; it is an important survival factor to decreased cross-KF into the nearshore water.

\section{CONCLUSION}

This paper presents the occurred and shift features of the KF and upwelling in the shelf waters in the southern ECS during the northeast monsoon period. Vertical profiles of temperature and salinity from field observations revealed that upwelling water is a year-round phenomenon that weakens as the thermal front strengthens in the study area during the northeast monsoon period. We collected 9896 larval fish between November 2012 and March 2016 and compared fish larval assemblages associated with the KF and upwelling. Over four cruises, variations were observed in the abundance and composition of fish larvae, which were influenced by spawning seasons. In particular, E. japonicus migrated from the offshore area to the coastal area alongside the CCC in the northeastern waters of Taiwan in March 2013. The causes of spatial variations in larval fish distribution may depend on the effects of hydrographic fea- tures and adult habitats. Figure 8 depicts the relationship between the hydrographic environment (including the $\mathrm{KC}$, $\mathrm{CCC}, \mathrm{KF}$, and upwelling) and the distribution of fish larvae in this study. Myctophid and gonostomatid fish species appeared on the continental shelf of the southern ECS as the KC intruded. Spatial distributions and compositions of fish larvae varied significantly with the seaward and shoreward movement of the KF and the Kuroshio. Even mesopelagic fish were brought into nearshore waters by Kuroshio water, but most larvae were still restricted to the offshore side by the KF. The generation of the KF may result in the crossfrontal transport of oceanic larval fish, with this effect being seen more intensely for oceanic fish than for neritic species because they engage in vertical migration behavior. However, coastal species may also be restricted to dispersal to oceanic waters by the KF; the effect on them may be more intense than that on the oceanic species. In the strong upwelling period, neritic fish can spread to and through the nutritious waters with the upwelling. The probability of the cross-KF transport of oceanic fish larvae may have been increased because the front was weakened, the competition for food with the neritic species may have become a decisive factor for this behavior. Upwelling and the thermal front affect the distribution of larval fish, with the stronger one influencing the distribution of larval fish more than the weaker one when they occur simultaneously. Nevertheless, the spatial scale of our study did not have a good resolution needed to reveal the vertical cross-frontal processes that occur at the frontal zones and affect the oceanic species. Through sampling at different depths, a future study may be able to determine which water layer is a major area for the cross-frontal transport of fish larvae in this area. Moreover, some remaining classification problems may be surmounted using genetic techniques, which can provide more detailed information on larval fish distributions.

Acknowledgements We thank the Ministry of Science and Technology for partially funding this research (MOST
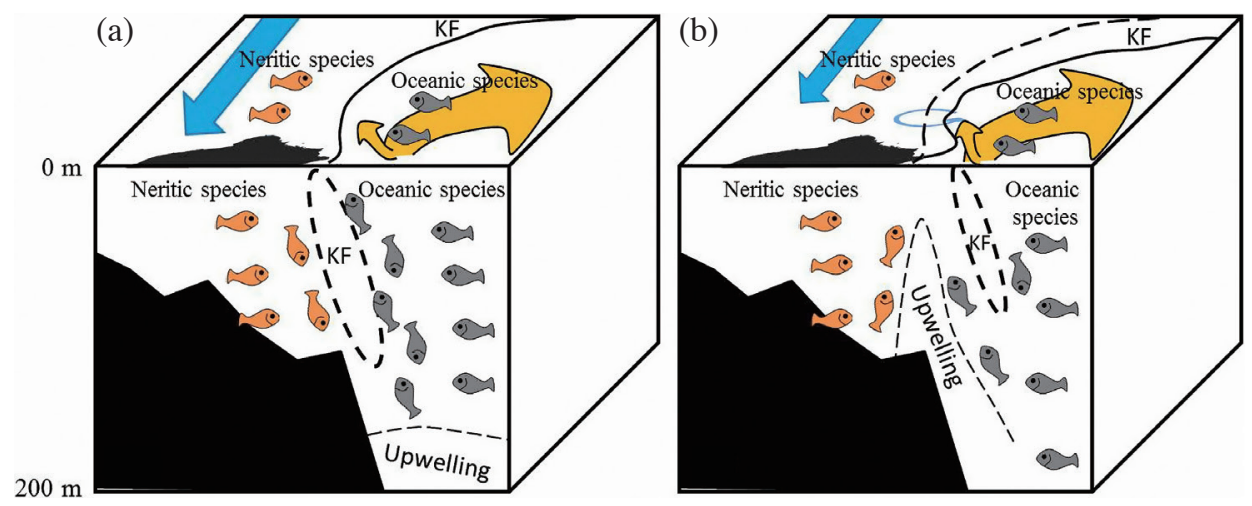

Fig. 8. Illustration of the relationship between the distribution and spread of fish larvae and variation of the Kuroshio Front and upwelling; (a) Kuroshio Front intrusion and (b) Kuroshio Front recession on the continental shelf of the southern East China Sea. 
102-2611-M-019-020 and 103-2611-M-019-009). We also thank the crew of the vessel Ocean Research II vessel for providing information and assistance. Last, we acknowledge Wallace Academic Editing for editing this manuscript.

\section{REFERENCES}

Bakun, A., 2006: Fronts and eddies as key structures in the habitat of marine fish larvae: Opportunity, adaptive response and competitive advantage. Sci.Mar., 70, 105122, doi: 10.3989/scimar.2006.70s2105. [Link]

Belkin, I. M., 2009: Rapid warming of Large Marine Ecosystems. Prog. Oceanogr., 81, 207-213, doi: 10.1016/j. pocean.2009.04.011. [Link]

Bolanos, M. A. and W.-N. Tzeng, 1994: Estimation of growth parameters of two species of mackerel, Scomber japonicus and S. australasicus, in the coastal waters of Taiwan. J. Fish. Soc. Taiwan, 21, 313-321, doi: 10.29822/JFST.199412.0002. [Link]

Bray, J. R. and J. T. Curtis, 1957: An ordination of the upland forest communities of southern Wisconsin. Ecol. Monogr., 27, 325-349, doi: 10.2307/1942268. [Link]

Butler, M., S. M. Bollens, B. Burkhalter, L. P. Madin, and E. Horgan, 2001: Mesopelagic fishes of the Arabian Sea: Distribution, abundance and diet of Chauliodus pammelas, Chauliodus sloani, Stomias affinis, and Stomias nebulosus. Deep-Sea Res. Part II-Top. Stud. Oceanogr., 48, 1369-1383, doi: 10.1016/S09670645(00)00143-0. [Link]

Carassou, L. and D. Ponton, 2009: Relative importance of water column vs zooplankton variables in the determination of late-stage larval fish assemblage structure in coastal waters of a coral reef lagoon. Sci. Mar., 73, 7384, doi: 10.3989/scimar.2009.73s1073. [Link]

Castro, M. S. D., W. J. Richards, and A. C. T. Bonecker, 2010: Occurrence and distribution of larval lanternfish (Myctophidae) from the southwest Atlantic Ocean. Zoologia (Curitiba), 27, 541-553, doi: 10.1590/S198446702010000400006. [Link]

Chang, Y., M.-A. Lee, T. Shimada, F. Sakaida, H. Kawamura, J.-W. Chan, and H.-J. Lu, 2008: Wintertime highresolution features of sea surface temperature and chlorophyll- $a$ fields associated with oceanic fronts in the southern East China Sea. Int. J. Remote Sens., 29, 6249-6261, doi: 10.1080/01431160802175462. [Link]

Chen, C.-S. and T.-S. Chiu, 1992: Comparison of ichthyoplankton guild in the Kuroshio edge exchange area. Terr. Atmos. Ocean. Sci., 3, 335-346, doi: 10.3319/ TAO.1992.3.3.335(KEEP). [Link]

Chen, C.-S. and T.-S. Chiu, 2003: Early life history traits of Japanese anchovy in the northeastern waters of Taiwan, with reference to larval transport. Zool. Stud., 42, 248-257.

Chen, W. Y., M. A. Lee, K. W. Lan, and G. C. Gong, 2014:
Distributions and assemblages of larval fish in the East China Sea during the northeasterly and southwesterly monsoon seasons of 2008. Biogeosciences, 11, 547561, doi: 10.5194/bg-11-547-2014. [Link]

Chen, Y.-K., W.-Y. Chen, Y.-C. Wang, and M.-A. Lee, 2016: Winter assemblages of ichthyoplankton in the waters of the East China Sea Shelf and surrounding Taiwan. Fish. Sci., 82, 755-769, doi: 10.1007/s12562016-1012-x. [Link]

Cheng, Y.-H., C.-R. Ho, Z.-W. Zheng, Y.-H. Lee, and N.-J. Kuo, 2009: An algorithm for cold patch detection in the Sea off northeast Taiwan using multi-sensor data. Sensors, 9, 5521-5533, doi: 10.3390/s90705521. [Link]

Chu, P., Y. Chen, and A. Kuninaka, 2005: Seasonal variability of the Yellow Sea/East China Sea surface fluxes and thermohaline structure. Adv. Atmos. Sci., 22, 1-20, doi: 10.1007/BF02930865. [Link]

Clarke, K. R. and R. N. Gorley, 2006: PRIMER v6: User Manual/Tutorial (Plymouth Routines in Multivariate Ecological Research), Primer-E Ltd., Plymouth.

Danell-Jiménez, A., L. Sanchez-Velasco, M. F. Lavín, and S. G. Marinone, 2009: Three-dimensional distribution of larval fish assemblages across a surface thermal/chlorophyll front in a semienclosed sea. Estuar. Coast. Shelf Sci., 85, 487-496, doi: 10.1016/j. ecss.2009.09.010. [Link]

DiBacco, C., D. Sutton, and L. McConnico, 2001: Vertical migration behavior and horizontal distribution of brachyuran larvae in a low-inflow estuary: Implications for bay-ocean exchange. Mar. Ecol. Prog. Ser., 217, 191-206, doi: 10.3354/meps217191. [Link]

Engström-Öst, J. and J. Mattila, 2008: Foraging, growth and habitat choice in turbid water: An experimental study with fish larvae in the Baltic Sea. Mar. Ecol. Prog. Ser., 359, 275-281, doi: 10.3354/meps07345. [Link]

Fiksen, Ø., D. L. Aksnes, M. H. Flyum, and J. Giske, 2002: The influence of turbidity on growth and survival of fish larvae: A numerical analysis. In: Vadstein, O. and Y. Olsen (Eds.), Sustainable Increase of Marine Harvesting: Fundamental Mechanisms and New Concepts, Developments in Hydrobiology, Vol. 167, Springer, Dordrecht, 49-59, doi: 10.1007/978-94-017-3190-4_5. [Link]

Franco, B. C., J. H. Muelbert, and M. M. Mata, 2006: Mesoscale physical processes and the distribution and composition of ichthyoplankton on the southern Brazilian shelf break. Fish Oceanogr., 15, 37-43, doi: 10.1111/j.1365-2419.2005.00359.x. [Link]

Gong, G.-C., Y.-L. Lee Chen, and K.-K. Liu, 1996: Chemical hydrography and chlorophyll a distribution in the East China Sea in summer: Implications in nutrient dynamics. Cont. Shelf Res., 16, 1561-1590, doi: 10.1016/0278-4343(96)00005-2. [Link]

Gong, G.-C., Y.-H. Wen, B.-W. Wang, and G.-J. Liu, 2003: 
Seasonal variation of chlorophyll a concentration, primary production and environmental conditions in the subtropical East China Sea. Deep-Sea Res. Part II-Top. Stud. Oceanogr., 50, 1219-1236, doi: 10.1016/S09670645(03)00019-5. [Link]

Hsieh, C.-H. and T.-S. Chiu, 2002: Summer spatial distribution of copepods and fish larvae in relation to hydrography in the northern Taiwan Strait. Zool. Stud., 41, 85-98.

Hsieh, C.-H., C.-S. Chen, T.-S. Chiu, K.-T. Lee, F.-J. Shieh, J.-Y. Pan, and M.-A. Lee, 2009: Time series analyses reveal transient relationships between abundance of larval anchovy and environmental variables in the coastal waters southwest of Taiwan. Fish Oceanogr., 18, 102-117, doi: 10.1111/j.1365-2419.2008.00498.x. [Link]

Hsieh, F.-J., M.-A. Lee, J.-Y. Pan, Y.-T. Wang, K.-W. Lan, and Y.-C. Lan, 2007: Winter distribution and composition of ichthyoplankton associated with thermal front on the continental shelf of the southern East China Sea. J. Fish. Soc. Taiwan, 34, 69-85, doi: 10.29822/ JFST.200703.0006. [Link]

Hsieh, H.-Y., W. T. Lo, D. C. Liu, and W. C. Su, 2010: Influence of hydrographic features on larval fish distribution during the south-westerly monsoon in the waters of Taiwan, western North Pacific Ocean. J. Fish Biol., 76, 2521-2539, doi: 10.1111/j.1095-8649.2010.02643.x. [Link]

Hsieh, H.-Y., W.-T. Lo, L.-J. Wu, D.-C. Liu, and W.-C. Su, 2011: Monsoon-driven succession of the larval fish assemblage in the East China Sea shelf waters off northern Taiwan. J. Oceanogr., 67, 159-172, doi: 10.1007/ s10872-011-0015-6. [Link]

Hsu, C. H., K. T. Lee, M. A. Lee, C. H. Liao, and H. J. Lu, 2000: Effects of seasonal environment changes on the mackerel purse seine fishery in the waters off northeast Taiwan monitored by satellite remote sensing. Aquaculture and Fisheries Resources Management, Proceedings of the Joint Taiwan-Australia Aquaculture and Fisheries Resource and Management Forum, Bull. Taiwan Fish. Res. Inst., 257-261.

Hsu, S.-C., F.-J. Lin, W.-L. Jeng, and T. Y. Tang, 1998: The effect of a cyclonic eddy on the distribution of lithogenic particles in the southern East China Sea. J. Mar. Res.,56, 813-832, doi: 10.1357/002224098321667387. [Link]

Iseki, K. and Y. Kiyomoto, 1997: Distribution and settling of Japanese anchovy (Engraulis japonicus) eggs at the spawning ground off Changjiang River in the East China Sea. Fish Oceanogr., 6, 205-210, doi: 10.1046/j.1365-2419.1997.00040.x. [Link]

Jan, S. and S.-Y. Chao, 2003: Seasonal variation of volume transport in the major inflow region of the Taiwan Strait: The Penghu Channel. Deep-Sea Res. Part
II-Top. Stud. Oceanogr., 50, 1117-1126, doi: 10.1016/ S0967-0645(03)00013-4. [Link]

Jan, S., J. Wang, C.-S. Chern, and S.-Y. Chao, 2002: Seasonal variation of the circulation in the Taiwan Strait. J. Mar. Syst., 35, 249-268, doi: 10.1016/S09247963(02)00130-6. [Link]

Jan, S., D. D. Sheu, and H.-M. Kuo, 2006: Water mass and throughflow transport variability in the Taiwan Strait. J. Geophys. Res., 111, C12012, doi: 10.1029/2006JC003656. [Link]

Jan, S., C.-C. Chen, Y.-L. Tsai, Y. J. Yang, J. Wang, C.S. Chern, G. Gawarkiewicz, R.-C. Lien, L. Centurioni, and J.-Y. Kuo, 2011: Mean structure and variability of the cold dome northeast of Taiwan. Oceanography, 24, 100-109, doi: 10.5670/oceanog.2011.98. [Link]

Kim, J.-Y., Y.-S. Kang, H.-J. Oh, Y.-S. Suh, and J.-D. Hwang, 2005: Spatial distribution of early life stages of anchovy (Engraulis japonicus) and hairtail (Trichiurus lepturus) and their relationship with oceanographic features of the East China Sea during the 1997-1998 El Niño Event. Estuar. Coast. Shelf Sci., 63, 13-21, doi: 10.1016/j.ecss.2004.10.002. [Link]

Lee, M.-A., Y.-C. Wang, Y.-K. Chen, W.-Y. Chen, L.-J. Wu, D.-C. Liu, J.-L. Wu, and S.-Y. Teng, 2013: Summer assemblages of ichthyoplankton in the waters of the east China Sea shelf and around Taiwan in 2007. J. Mar. Sci. Technol., 21, 41-51, doi: 10.6119/JMST013-1219-5. [Link]

Leis, J. M., 2006: Are larvae of demersal fishes plankton or nekton? Adv. Mar. Biol., 51, 57-141, doi: 10.1016/ S0065-2881(06)51002-8. [Link]

Liang, W.-D., T. Y. Tang, Y. J. Yang, M. T. Ko, and W.-S. Chuang, 2003: Upper-ocean currents around Taiwan. Deep-Sea Res. Part II-Top. Stud. Oceanogr., 50, 10851105, doi: 10.1016/S0967-0645(03)00011-0. [Link]

Liao, C.-H., M.-A. Lee, Y.-C. Lan, and K.-T. Lee, 2006: The temporal and spatial change in position of squid fishing ground in relation to oceanic features in the Northeastern waters of Taiwan. J. Fish. Soc. Taiwan, 33, 99-113, doi: 10.29822/JFST.200606.0002. [Link]

Lie, H.-J. and C.-H. Cho, 2002: Recent advances in understanding the circulation and hydrography of the East China Sea. Fish Oceanogr., 11, 318-328, doi: 10.1046/j.1365-2419.2002.00215.x. [Link]

Lin, C.-Y., C.-Z. Shyu, and W.-H. Shih, 1992: The Kuroshio fronts and cold eddies off northeastern Taiwan observed by NOAA-AVHRR imageries. Terr. Atmos. Ocean. Sci., 3, 225-242, doi: 10.3319/ TAO.1992.3.3.225(KEEP). [Link]

Liu, K.-K., G.-C. Gong, S. Lin, C.-Y. Yang, C.-L. Wei, S.-C. Pai, and C.-K. Wu, 1992: The year-round upwelling at the shelf break near the northern tip of Taiwan as evidenced by chemical hydrography. Terr. Atmos. Ocean. Sci., 3, 243-276, doi: 10.3319/ 
TAO.1992.3.3.243(KEEP). [Link]

Lo, W. T., H. Y. Hsieh, L. J. Wu, H. B. Jian, D. C. Liu, and W. C. Su, 2010: Comparison of larval fish assemblages between during and after northeasterly monsoon in the waters around Taiwan, western North Pacific. J. Plankton Res., 32, 1079-1095, doi: 10.1093/plankt/ fbq034. [Link]

Loeb, V. J. and A. J. Nichols 1984: Vertical distribution and composition of ichthyoplankton and invertebrate zooplankton assemblages in the eastern tropical Pacific. Biología pesquera, 13, 39-66.

Martins, A. S. and M. Haimovici, 1997: Distribution, abundance and biological interactions of the cutlassfish Trichiurus lepturus in the southern Brazil subtropical convergence ecosystem. Fish. Res., 30, 217-227, doi: 10.1016/S0165-7836(96)00566-8. [Link]

Moku, M., A. Tsuda, and K. Kawaguchi, 2003: Spawning season and migration of the myctophid fish Diaphus theta in the western North Pacific. Ichthyol. Res., 50, 52-58, doi: 10.1007/s102280300007. [Link]

Morgan, S. G., J. L. Fisher, S. H. Miller, S. T. McAfee, and J. L. Largier, 2009: Nearshore larval retention in a region of strong upwelling and recruitment limitation. Ecology, 90, 3489-3502, doi: 10.1890/08-1550.1. [Link]

Moser, G. H. and P. E. Smith, 1993: Larval fish assemblages of the California Current region and their horizontal and vertical distributions across a front. Bull.Mar. Sci., 53, 645-691.

Ochiai, A., K. Mutsutani, and S. Umeda, 1983: On the first year's growth, maturity and artificial spawning of cultured jack mackerel. Bull.Jpn. Soc. Sci. Fish., 49, 541545.

Oey, L.-Y., Y.-C. Hsin, and C.-R. Wu, 2010: Why does the Kuroshio northeast of Taiwan shift shelfward in winter? Ocean Dyn., 60, 413-426, doi: 10.1007/s10236009-0259-5. [Link]

Ohshimo, S., T. Yasuda, H. Tanaka, and C. Sassa, 2012: Biomass fluctuation of two dominant lanternfish Diaphus garmani and D. chrysorhynchus with environmental changes in the East China Sea. Fish. Sci., 78, 33-39, doi: 10.1007/s12562-011-0424-x. [Link]

Okazaki, Y. and H. Nakata, 2007: Effect of the mesoscale hydrographic features on larval fish distribution across the shelf break of East China Sea. Cont. Shelf Res., 27, 1616-1628, doi: 10.1016/j.csr.2007.01.024. [Link]

Okiyama, M., 1988: An Atlas of the Early Stage Fishes in Japan, Tokai University Press, Tokyo, 1154 pp.

Omori, M. and T. Ikeda, 1984: Methods in Marine Zooplankton Ecology, John Wiley \& Sons, New York, 332 pp.

Queiroga, H., J. D. Costlow, and M. H. Moreira, 1997: Vertical migration of the crab Carcinus maenas first zoea in an estuary: Implications for tidal stream transport.
Mar. Ecol. Prog. Ser., 149, 121-132, doi: 10.3354/ meps 149121. [Link]

Rao, K. V., 1983: Maturation and spawning of lizard fishes (Saurida spp.) From Northwestern part of bay of Bengal. Indian J. Fish., 30, 27-45.

Reiss, C. S. and J. R. McConaugha, 1999: Cross-frontal transport and distribution of ichthyoplankton associated with Chesapeake Bay plume dynamics. Cont. Shelf Res., 19, 151-170, doi: 10.1016/S02784343(98)00080-6. [Link]

Sabatés, A., 1990: Distribution pattern of larval fish populations in the Northwestern Mediterranean. Mar. Ecol. Prog. Ser., 59, 75-82, doi: 10.3354/meps059075. [Link]

Sabatés, A. and M. P. Olivar, 1996: Variation of larval fish distributions associated with variability in the location of a shelf-slope front. Mar. Ecol. Prog. Ser., 135, 1120, doi: 10.3354/meps 135011. [Link]

Sassa, C. and Y. Hirota, 2013: Seasonal occurrence of mesopelagic fish larvae on the onshore side of the Kuroshio off southern Japan. Deep-Sea Res. Part I-Oceanogr. Res. Pap., 81, 49-61, doi: 10.1016/j.dsr.2013.07.008. [Link]

Sassa, C. and K. Kawaguchi, 2006: Occurrence patterns of mesopelagic fish larvae in Sagami Bay, central Japan. J. Oceanogr., 62, 143-153, doi: 10.1007/s10872-0060040-z. [Link]

Sassa, C. and Y. Konishi, 2015: Late winter larval fish assemblage in the southern East China Sea, with emphasis on spatial relations between mesopelagic and commercial pelagic fish larvae. Cont. Shelf Res., 108, 97-111, doi: 10.1016/j.csr.2015.08.021. [Link]

Sassa, C. and Y. Tsukamoto, 2010: Distribution and growth of Scomber japonicus and S. australasicus larvae in the southern East China Sea in response to oceanographic conditions. Mar. Ecol. Prog. Ser., 419, 185-199, doi: 10.3354/meps08832. [Link]

Sassa, C., K. Kawaguchi, and K. Mori, 2004a: Late winter larval mesopelagic fish assemblage in the Kuroshio waters of the western North Pacific. Fish Oceanogr., 13, 121-133, doi: 10.1046/j.1365-2419.2003.00275.x. [Link]

Sassa, C., K. Kawaguchi, Y. Hirota, and M. Ishida, 2004b: Distribution patterns of larval myctophid fish assemblages in the subtropical-tropical waters of the western North Pacific. Fish Oceanogr., 13, 267-282, doi: 10.1111/j.1365-2419.2004.00289.x. [Link]

Sassa, C., K. Kawaguchi, Y. Oozeki, H. Kubota, and H. Sugisaki, 2004c: Distribution patterns of larval myctophid fishes in the transition region of the western North Pacific. Mar. Biol., 144, 417-428, doi: 10.1007/ s00227-003-1214-5. [Link]

Sassa, C., Y. Konishi, and K. Mori, 2006: Distribution of jack mackerel (Trachurus japonicus) larvae and 
juveniles in the East China Sea, with special reference to the larval transport by the Kuroshio Current. Fish Oceanogr., 15, 508-518, doi: 10.1111/j.13652419.2006.00417.x. [Link]

Sassa, C., K. Kawaguchi, and K. Taki, 2007: Larval mesopelagic fish assemblages in the Kuroshio-Oyashio transition region of the western North Pacific. Mar. Biol., 150, 1403-1415, doi: 10.1007/s00227-0060434-x. [Link]

Sassa, C., Y. Tsukamoto, and Y. Konishi, 2008a: Diet composition and feeding habits of Trachurus japonicus and Scomber spp. larvae in the shelf break region of the East China Sea. Bull. Mar. Sci., 82, 137-153.

Sassa, C., Y. Tsukamoto, K. Nishiuchi, and Y. Konishi, 2008b: Spawning ground and larval transport processes of jack mackerel Trachurus japonicus in the shelfbreak region of the southern East China Sea. Cont. Shelf Res., 28, 2574-2583, doi: 10.1016/j.csr.2008.08.002. [Link]

Sassa, C., Y. Tsukamoto, K. Yamamoto, and M. Tokimura, 2010: Spatio-temporal distribution and biomass of Benthosema pterotum (Pisces: Myctophidae) in the shelf region of the East China Sea. Mar. Ecol. Prog. Ser., 407, 227-241, doi: 10.3354/meps08526. [Link]

Shannon, C. E. and W. Weaver, 1963: The Mathematical Theory of Communication, University of Illinois Press, Urbana.

Su, W.-C., W.-T. Lo, D.-C. Liu, L.-J. Wu, and H.-Y. Hsieh, 2011: Larval fish assemblages in the Kuroshio waters east of Taiwan during two distinct monsoon seasons. Bull. Mar. Sci., 87, 13-29, doi: 10.5343/ bms.2010.1010. [Link]

Takahashi, M. and Y. Watanabe, 2004: Growth rate-dependent recruitment of Japanese anchovy Engraulis japonicus in the Kuroshio-Oyashio transitional waters. Mar. Ecol. Prog. Ser., 266, 227-238, doi: 10.3354/ meps266227. [Link]

Takano, K., A. Takemura, M. Furihata, T. Nakanishi, and A. Hara, 1991: Annual reproductive and spawning cycles of female Sebastiscus marmoratus. In: Boehlert, G. W. and J. Yamada (Eds.), Rockfishes of the Genus Sebastes: Their Reproduction and Early Life History, Developments in Environmental Biology of Fishes, Vol. 11, Springer, Dordrecht, 39-48, doi: 10.1007/97894-011-3792-8_5. [Link]

Tang, T. Y., J. H. Tai, and Y. J. Yang, 2000: The flow pattern north of Taiwan and the migration of the Kuroshio. Cont. Shelf Res., 20, 349-371, doi: 10.1016/ S0278-4343(99)00076-X. [Link]

Tiedemann, M. and P. Brehmer, 2017: Larval fish assemblages across an upwelling front: Indication for active and passive retention. Estuar. Coast. Shelf Sci., 187, 118-133, doi: 10.1016/j.ecss.2016.12.015. [Link]

Tu, C.-Y., Y.-H. Tseng, T.-S. Chiu, M.-L. Shen, and C.-
H. Hsieh, 2012: Using coupled fish behavior-hydrodynamic model to investigate spawning migration of Japanese anchovy, Engraulis japonicus, from the East China Sea to Taiwan. Fish Oceanogr., 21, 255-268, doi: 10.1111/j.1365-2419.2012.00619.x. [Link]

Tzeng, W.-N., 1984: The historical review and develop of mackerel purse seine fishery in Taiwan. China Fisheries Monthly, 375, 35-52. (in Chinese)

Tzeng, W.-N., Y.-T. Wang, and Y. T. Chern, 1997: Species composition and distribution of fish larvae in Yenliao Bay, northeastern Taiwan. Zool. Stud., 36, 146-158.

Uehara, S. and T. Mitani, 2002: Distribution of jack mackerel larvae and juveniles in the Japan coastal region of the Pacific. Kaiyo Monthly, 31, 99-105. (in Japanese)

Vargas, C. A. and L. R. Castro, 2001: Spawning of the chilean hake (Merluccius gayi) in the upwelling system off Talcahuano in relation to oceanographic features. Sci. Mar., 65, 101-110, doi: 10.3989/scimar.2001.65n2101. [Link]

Walsh, J. J., 1991: Importance of continental margins in the marine biogeochemical cycling of carbon and nitrogen. Nature, 350, 53-55, doi: 10.1038/350053a0. [Link]

Wang, J. T.-M. and C.-T. Chen, 2001: A review of lanternfishes (families: Myctophidae and Neoscopelidae) and their distributions around Taiwan and the Tungsha Islands with notes on seventeen new records. Zool. Stud., 40, 103-126.

Wang, Y.-C., W.-Y. Chen, Y. Chang, and M.-A. Lee, 2013: Ichthyoplankton community associated with oceanic fronts in early winter on the continental shelf of the southern East China Sea. J. Mar. Sci.Technol., 21, 6576, doi: 10.6119/JMST-013-1219-6. [Link]

Wang, Y.-C., J.-W. Chan, Y.-C. Lan, W.-C. Yang, and M.-A. Lee, 2018: Satellite observation of the winter variation of sea surface temperature fronts in relation to the spatial distribution of ichthyoplankton in the continental shelf of the southern East China Sea. Int. J. Remote Sens., 39, 4550-4564, doi: 10.1080/01431161.2017.1407053. [Link]

Wang, Y.-T., C.-L. Lee, C.-I. Pan, S.-H. Wu, C.-T. Tseng, and Y.-X. Cheng, 2006: Species composition and distribution of fish larvae and juveniles in the waters off northeastern Taiwan in spring 2005 with particular reference to mackerel and scad. J. Taiwan Fish. Res., 14, 27-44.

Watanabe, H., M. Moku, K. Kawaguchi, K. Ishimaru, and A. Ohno, 1999: Diel vertical migration of myctophid fishes (Family Myctophidae) in the transitional waters of the western North Pacific. Fish Oceanogr., 8, 115127, doi: 10.1046/j.1365-2419.1999.00103.x. [Link]

Wollast, R., 1993: Interactions of carbon and nitrogen cycles in the coastal zone. In: Wollast, R., F. T. Mackenzie, L. Chou (Eds.), Interactions of $\mathrm{C}, \mathrm{N}, \mathrm{P}$ and $\mathrm{S}$ Biogeochemical Cycles and Global Change, NATO 
ASI Series (Series I: Global Environmental Change), Vol. 4, Springer, Berlin, Heidelberg, 195-210, doi: 10.1007/978-3-642-76064-8_7. [Link]

Wu, C.-R., H.-F. Lu, and S.-Y. Chao, 2008: A numerical study on the formation of upwelling off northeast Taiwan. J. Geophys. Res., 113, C08025, doi: 10.1029/2007JC004697. [Link]

Yannicelli, B., L. R. Castro, W. Schneider, and M. Sobarzo, 2006: Crustacean larvae distribution in the coastal upwelling zone off central Chile. Mar. Ecol. Prog. Ser., 319, 175-189, doi: 10.3354/meps319175. [Link]

Yoneda, M., T. Sakai, M. Tokimura, H. Horikawa, and M. Matsuyama, 2002: Age and growth of the lizardfish Saurida sp. 1 in the East China Sea using otolith ring marks. Fish. Res., 55, 231-238, doi: 10.1016/S01657836(01)00285-5. [Link]

Yukami, R., S. Ohshimo, M. Yoda, and Y. Hiyama, 2009: Estimation of the spawning grounds of chub mackerel Scomber japonicus and spotted mackerel Scomber australasicus in the East China Sea based on catch statistics and biometric data. Fish. Sci., 75, 167-174, doi: 10.1007/s12562-008-0015-7. [Link]

Zhang, C. I. and J. B. Lee, 2001: Stock assessment and management implications of horse mackerel (Trachurus japonicus) in Korean waters, based on the relationships between recruitment and the ocean environment. Prog. Oceanogr., 49, 513-537, doi: 10.1016/S00796611(01)00038-6. [Link] 